\title{
Study on the Phytochemical Analysis and Antioxidants, Antimicrobial Activity of Medicinal Plants against Fish Pathogen
}

\author{
Authors \\ Thamarai Sridevi,.K ${ }^{1}$, J.Poovizhi ${ }^{2}$, Dr V.Senthil Kumar ${ }^{3}$ \\ ${ }^{1}$ Dept of Biotechnogy, Maharaja Co-Education Arts and Science College, Perundhurai \\ ${ }^{2}$ Dept of Biotechnogy, Ass Professor Nandha Arts and Science College, Perundhurai
}

${ }^{3}$ Dept of Biotechnogy, Head of the Dept, Maharaja Co-Education Arts and Science College, Perundhurai

\begin{abstract}
The present study was designed to evaluate the phytochemical screening, antioxidants and antimicrobial activities of different plants extracts. Phytochemical screening revealed the presence of terphenols, phenols, quinone, carbohydrates, flavonoid, tannin, saponion, and also screening total content of flavonoid and tannin ,phenol, and antioxidant capacity are extract the plant part of leaves. The powdered plants are extracting with methanol further fractioned with hexane. The total content of tannin is higher in carciya papaya 1.963, total ascorbic acid content higher in carciya papaya. Free radical scavenging activities are higher in carciya papaya 1.642. The total phenol concentration is higher pomengrate. The total flavonoid content has higher in pomengrate and carciya papaya. The reducing power assays are higher in solanum nigrum 0.765. The microorganisms are isolated from fish pathogen. The antimicrobial activity is higher in pomengrate $19 \pm 0.1$. Thin layer chromatography are used to separate the phytochemicals flavonoid, Caumarrins, alkaloid. After 24 hours plates were incubated and using MTT assay (2, 4 Terphenols tetrazolium). The inhibition areas are changed in pink or violet.
\end{abstract}

Keywords: Phytochemicals, antioxidant ,MIC,

Abbrevation: TLC-Thin layer chromatography,DPPH-1,1-diphenyl-2-picryl-hydrazyl

\section{INTRODUCTION}

Ayurveda has, for several years, exalted the virtues of the vegetarian diet emphasizing on the benefits of green leafy vegetables. Although greens, like spinach have gained universal acceptance through the vastly popular Popeye, they have always been part of the staple diet recommended by Ayurveda physicians. Greens are rich in fiber and antioxidants and contain natural pigments like lute in that keep several diseases, such as macular degeneration, at bay. Ayurveda recommends that greens be included as part of every individual's daily diet to cure diseases.
For thousands of years, the practice of Ayurveda medicine has alleviated illness and attributed over all positive health. The Indian subcontinent has a rich flora of various plants used in traditional medicinal treatment. The plants contain different bioactive ingredients used to cure disease or relieve pain (Samy et al 2008). The medicinal properties of these plants could be based on the antioxidant; antimicrobial effects of different phytochemicals present them. Recently the side effects associated with the use of allopathic drugs have resulted in an increased dement for the phytopharmaceutical products of Ayurveda. (Hedge Chaitra et al.,2012) 
The plants derived antioxidant $\mathrm{s}$ especially phenolichas gained considerable importance due to their potential health benefits. Epidemiological studies have consumption of plant foods containing antioxidant's is beneficial to health because it down regulates many degenerative process and can effectively lower the incidence of cancer and cardiac vascular disease. (Arabshahi, 2007)

Plants derived antioxidants are regarded as effective in controlling the effects of oxidative damage, and hence have had influence in what people eat and drink. The ant oxidative effect is mainly due to phenolic components, such as flavonoids, phenolic acids, and phenolic diterpenes (Shahidi et al., 1992). The antioxidant capacity of phenolic compounds is mainly due to their redox properties, which can play an important role in absorbing and neutralizing free radicals, quenching singlet and triplet oxygen, or decomposing peroxides (Acharya 2004). Oxidative stress involving enhanced generation of reactive oxygen species (ROS) has been implicated in the etiology of over one hundred human diseases including inflammation, metabolic disorders, cellular aging and atherosclerosis, heart disease, stroke, diabetes mellitus, cancer, malaria, rheumatoid arthritis and HIV/AIDS (Aravind, Bhowmik, 2013) Antioxidants are molecules that are capable of neutralizing the harmful effects of the ROS through the endogenous enzymatic defense system such as the superoxide dismutase (SOD), glutathione peroxidase (GPX) and catalase (CAT) in human system. However, with the increasing damaging environmental factors such as cigarette smoke, uvrays, radiation and toxic chemicals; the endogenous defense system is weakened, resulting to a phenomenal disturbance in the equilibrium status of pro-oxidant/antioxidants reactions in living systems. This situation mediates damage to cell structures, including lipids and membranes, proteins, and DNA.

The medicinal plant selected from the present investigation which included punicagranatum (pomengrate), Mentha spicata (menthol), carciyapapaya (papaya), solanum nigrum (Manathakali), Indian goose berry (Nellikai) have long been used in folk medicine due to their potential health promoting and pharmacological attributes which mainly ascribed to the presence of antioxidants constituents. Such as Flavonoids, alkaloid, saponins, terphenols, Carbohydrates, Tannin, Phenols, Quinone etc., And also study about antimicrobial activity of plant extracts against fish pathogens.

\section{CARCIYA PAPAYA}

Carica papaya Linnaeus, (pawpaw), belongs to the family of Caricaceae. Papaya is not a tree but herbaceous succulent plants that possess selfsupporting stems. Papaya is a large perennial herb with a rapid growth rate. The plants are usually short lived, but can produce fruit for more than 20years. The papaya has a rather complicated means of reproduction. The plants are male, hermaphrodite, or female (Bruce and Peter, 2008). The male trees are uncommon, but sometimes occur when homeowners collect their own seeds. Hermaphrodite trees (flowers with male and female parts) are the commercial standard, producing a pear shaped fruit. These plants are self-pollinated.

Carica papaya plants produce natural compounds (annonaceousacetogenins) in leaf bark and twig tissues that possess both highly anti-tumors and pesticides properties. The high level of natural self-defense compounds in the tree makes it highly resistant to insect and disease infestation (Peter, 2008). Carica papaya L. leaf tea or extract has a reputation as a tumors-destroying agent. The papaya fruit, as well as all other parts of the plant, contain a milky juice in which an active principle known as papain is present. Aside from its value as a remedy in dyspepsia and kindred ailments, it has been utilized for the clarification of beer. The juice has been in use on meat to make it tender.

\section{INDIAN GOOSEBERRY}

Amla is a Phyllanthacae Family. It is an indispensable part of the ayurvedic and unani system with amazing remedial qualities. In 
Sanskrit, it is called Amalaki or Dhartiphala (Onions, 1994).

In India, it is common to eat gooseberries steeped in salt water and turmeric to make the sour fruits palatable. There are two varieties of Amla cultivated (gramya) and wild (vanya). The wild amla is small, while cultivated amla is big, smooth and juicy. Chemical composition of the amla fruit contains more than $80 \%$ of water. It also has protein, carbohydrate, fiber and mineral and also contains gallic acid which is a potent polyphenol. Vitamin $\mathrm{C}$ is important for human beings. The amla fruit is reported to contain nearly 20 times as much vitamin $\mathrm{C}$ as orange juice. The edible amla fruit tissue has 3 times the protein concentration and 160 times the ascorbic acid concentration of an apple. The fruit also contains higher concentration of most minerals and amino acids than apples. Amla fruit ash contains chromium, Zinc and copper. It is considered as adaptogenic that improves immunity.

The active ingredient that has significant pharmacological action in amla is designated by Indian scientist as "Phyllemblin". The fruit is rich in quercetin, phyllaemblic compounds, gallic acid, tannins, flavonoids, pectin, and vitamin $\mathrm{C}$ and also contains various polyphenolic compounds. A wide range of phytochemical components including terpenoids, alkaloids, flavonoids, and tannins have been shown to posses' useful biological (Aiyeloja2006).

\section{MENTHA PIPERITIA}

Mentha, a member of the Labiatae family is originated from Eastern Asia. Among the two major forms, namely Mentha piperitaL. and Mentha spicata L. Mentha spicata is locally known as 'Pudina' in Bangladesh. Its English name is Spearmint which is $30-100 \mathrm{~cm}$ long and is characterized by its strong odor (Kriter Basu, 1975).

Indian and Eastern Asian people use spearmint as a common constituent in their diet. It is used with spices to give the food a special flavor and fragrance, also used for flavoring chewing gums, toothpaste, confectionery and pharmaceutical preparations [Sugimura et al2004].Spearmint essential oil is a common constituent in hygiene and cosmetic products, and substantial amounts are used in the food and beverage industries [Bhattacharya et al1999]. The dry or fresh leaves of spearmint are added by the Middle East and African during the brewing of tea, where it provides a pleasant aroma and refreshing taste [Biswas, 2011]. There was an investigation that confirmed that spearmint had significant inhibitory effects against the cooked meat heterocyclic amine mutagen both in vitro and in vivo Mentha spicata has high traditional medicinal value as it is one of the important constituents of Ayurveda, Homeopathy and Siddha systems of medicine. Menthal can be used for common cold, cough, sinusitis, fever, bronchitis, nausea, vomiting, indigestion, intestinal colic and loss of appetite. It can have a calming effect when used for insomnia or massages. Essential oil of Spearmint was found to have some antimicrobial activity. It is also a safe and effective therapeutic option for the treatment of chemotherapy induced nausea and emesis in patients.

\section{PUNICA GRANATUM}

Punicagrantanum L, commenly known as pomengrate family puniaceae belong to family Lythraceae. The leaves are shiny and about 7.6 cm long (Hedge Chaitra et al.,2012) .

In the ancient Ayurveda system of medicine, the pomegranate has extensively been used as a source of traditional remedies for thousands of years. The rind of the fruit and the bark of the pomegranate tree is used as a traditional remedy against diarrhea, dysentery and intestinal parasites. The seeds and juice are considered a tonic for the heart, throat, eyes and for a variety of purposes, such as stopping nose bleeds and gum bleeds, toning skin, firming-up sagging breasts and treating hemorrhoids. (Chithra2000)

In the past decade, numerous studies on the antioxidant, anti carcinogenic, and antiinflammatory properties of pomegranate constituents have been published, focusing on treatment and prevention of cancer, cardiovascular 
disease, diabetes, dental conditions, erectile dysfunction, bacterial infections and antibiotic resistance, and ultraviolet radiation-induced skin damage. Other potential applications include infant brain ischemia, male infertility, Alzheimer's disease, arthritis, and obesity. In treating diarrhea, dysentery and intestinal parasites. Pomegranate is well known for antioxidant properties. It helps in preventing the formation of skin cancer by reducing the frequency of lesions. It provides relief from minor skin irritations, such as dry skin, eczema and psoriasis. (Jain, 2000)

\section{Health Benefits of Pomegranate Medicinal Benefits}

Pomegranate is a poly-vitamin, a unique fruit plant producing a wide spectrum of biologically active substances especially important in our present-day polluted environment. It helps in preventing the harmful effects of radioactive substances by producing biologically active substances. Russians, after the deadly Chernobyl tragedy, used pomegranates to reduce the effect of radioactive substances. In order to maintain the health and energy levels of astronomers, submariners and coal miners, they often consume pomegranate juice regularly. (Mohammad Ali Ebrahimzadeh et al., 2008) Pomegranate is loaded with tannins, anthocyanin, and polyphenols' and antioxidant vitamins, A, E and C, all of which have a health effect on the body. These elements work together to benefit the arteries, plus it keeps the cardiovascular system healthy which is the chief health benefit of Pomegranate It has also been found to increase levels of nitric oxide, which improve blood flow to the heart, reduce arterial plaque, reduce systolic blood pressure and help in curing erectile dysfunction. Other benefits include preventing premature aging, stroke, arthritis, Alzheimer's and even cancer. The juice of the red pomegranate has received attention for its rich flavor and health boosting properties. The juice comes from the crushed seeds. Pomegranate juice has been shown to contain more antioxidants than most fruit juices, red wine or green tea, according to Health Castle. (Kulkarni et al.,2001)

\section{SOLANUM NIGRUM}

Solanum nigrum (black nightshade) is a medicinal plant member of the Solanaceae family of plants. !is family comprises many genera, well known for their therapeutic properties. In addition to $S$. nigrum, this family includes fruits and vegetables such as potato (Solanumtuberosum), tomato, and peppers, ornamental plants such as petunia, and other medicinal plants such as Atropabelladonna L. (deadly nightshade), Daturastramonium L. (Jimson weed), and Hyoscyamusniger L. (black henbane). S. nigrum has been extensively used traditionally to treat various ailmentssuch as pain, inflammation and fever. plant is also used in the Orientalsystems of medicine for various purposes - as a antitumorigenic, antioxidant, antiinflammatory, hepatoprotective, diuretic, and antipyretic agent. Various compounds have been identified which are responsible for diverse activities. (Jain et al 2011)

$S$. nigrum has been used traditionally to treat various ailments such as pain, inflammation fever5 and enteric diseases. It possess many activities like antitumorigenic, antioxidant, antiinflammatory, hepatoprotective, diuretic, and antipyretic agent, antibacterial, mycotic infection, cytotoxicity, anti-convulsant, antiulcerogenic. It is also used against sexually transmitted diseases. Ethanol extract of Solanum nigrum is used to determine phytochemicals contents of leaves of Solanumnigrum L. Subjected to different processing methods were evaluated Processing procedures adopted include shredding, sundrying, oven-drying, steaming and a combination of these. Minerals examined are $\mathrm{Na}, \mathrm{K}, \mathrm{Ca}, \mathrm{Mg}$, $\mathrm{Fe}, \mathrm{P}$, and $\mathrm{Zn}$ while the phytochemicals are alkaloids, flavonoids, hydrocyanic acid, phenols, phytic acid and tannins. Oven - drying was the most effective method for retaining the studied minerals in S. nigrum but only for $\mathrm{Na}, \mathrm{Ca}, \mathrm{Fe}$ and $\mathrm{Mg}$. The phytochemical screening of the crude extract show the presence of alkaloids, reducing sugars, tannis, flavonoids, phlobatannins and steroids. (Zakaria et al.2006)

The present study is focus on the phytochemical analysis, Antioxidants and Antimicrobial activity 
of medicinal plant against fish pathogens. Such as E .coli , Staphylococcus aureus, Klebsilla, Salmonella, Streptococcus . Finally plant extracts used we analyses for minimal inhibitory concentration by fish pathogens and agar diffusion method. Thin layer chromatographyare used. TLC Plates are used for bio autography we can identify the phytochemical constituents and screening the antimicrobial activity of the plant extracts.

\section{MATERIALS AND METHODS}

\section{Plant collection}

Plants leaves were collected from home. Leaves of this plant were dried at $25^{\circ} \mathrm{C}$ and then grounded with a blender (Coffee grinder Model A979) and stored at approximately $4 \mathrm{C}$ until required for use.

\section{Preparation of Plant Extract}

$10 \mathrm{~g}$ of powdered leaves were placed in conical flask and $100 \mathrm{ml}$ of methanol was added and plugged with cotton. The powder material was extracted with methanol for 24 hours at room Temperature with continuous stirring. After 24 hours the supernatant was collected by filtration and the solvent was evaporated to make the crude extract. The residues obtained were Stored in airtight bottles in a refrigerator for further use.

\section{QUALITATIVE DETERMINATION \\ Preliminary Phytochemical Screening}

The methanol extracts of following plants was subjected to different chemical tests for the detection of different phyto constituents using standard procedures.

\section{Test for Tannins:}

$1 \mathrm{ml}$ of the sample was taken in a test tube and then $1 \mathrm{ml}$ of $0.008 \mathrm{M}$ Potassium ferricyanide was added. $1 \mathrm{ml}$ of $0.02 \mathrm{M}$ Ferric chloride containing $0.1 \mathrm{~N}$ Hydrochloric acid was added and Observed for blue-black colouration.

\section{Test for Phlobotanin}

When crude extract of each plant sample was boiled with $2 \%$ aqueous $\mathrm{HCl}$. The deposition of a red precipitate was taken as evidence for the presence of phlobatannins.

\section{Test for Saponins:}

Crude extract was mixed with $5 \mathrm{ml}$ of distilled water in a test tube and it was shaken vigorously. Add some drops of olive oil. The formation of stable foam was taken as an indication for the presence of saponins.

\section{Test for Flavonoids:}

$5 \mathrm{ml}$ of dilute ammonia solution were added to a portion of the crude extract followed by addition of concentrated $\mathrm{H} 2 \mathrm{SO} 4$. A yellow colouration observed in each extract indicated the presence of flavonoids. The yellow colouration disappeared on standing.

\section{Test for Alkaloids:}

Crude extract was mixed with $2 \mathrm{ml}$ of Wagner's reagent. Reddish brown colored precipitate indicates the presence of alkaloids.

\section{Test for Quinones:}

Dilute $\mathrm{NaOH}$ was added to the $1 \mathrm{ml}$ of crude extract. Blue green or red coloration indicates the presence of quinones.

\section{Test for Coumerin:}

$10 \%$ Sodiumhydroxide $(\mathrm{NaOH})$ was added to the extract and chloroform was added for observation of yellow color, which shows the presence of caumarrins.

\section{Test for Terpenoids (Salkowski test):}

$5 \mathrm{ml}$ of extract was mixed with $2 \mathrm{ml}$ of chloroform and $3 \mathrm{ml}$ of concentrated $\mathrm{H} 2 \mathrm{SO} 4$ was carefully added to form a layer. A reddish brown colouration of the inter face was formed to show positive results for the presence of terpenoids.

\section{QUANTITATIVE DETERMINATION \\ Determination of Total Phenolic Content}

Total Phenolic Content (TPC) in entophytic extracts was determined using Folin-Ciocalteu's colorimetric method. To $5 \mathrm{ml}$ of $0.3 \% \mathrm{HCl}$ in methanol/deionized water $(60: 40, \mathrm{v} / \mathrm{v}), 100 \mathrm{mg}$ of the ethanol extract was added. From the resulting mixture $(100 \mu \mathrm{l})$ was added to $2 \mathrm{ml}$ of $2 \%$ aqueous sodium carbonate. The mixture was incubated for $2 \mathrm{~min}$. To that $100 \mu \mathrm{l}$ of $50 \%$ FolinCiocalteu's reagent was added and incubated for $30 \mathrm{~min}$, absorbance was measured at $750 \mathrm{~nm}$ against blank. The content of total phenol was 
calculated on the basis of the calibration curve of Gallic acid and the results were expressed as mg of Gallic acid equivalents (GAEs) per $g$ of extract].

\section{Flavonoid Determination}

The leaves extract $(250 \mu \mathrm{l})$ was mixed with distilled water $(1.25 \mathrm{ml})$ and $\mathrm{NaNO} 2$ solution $(5 \%, 75 \mu \mathrm{l})$. After $5 \mathrm{~min}$ the $\mathrm{AlCl} 3 \mathrm{H} 2 \mathrm{O}$ solution $(10 \%, 150 \mu \mathrm{l})$ was added. After $6 \mathrm{~min}, \mathrm{NaOH}$ $(1 \mathrm{M}, 500 \mu \mathrm{l})$ and distilled water $(275 \mu \mathrm{l})$ were added to the mixture. The solution was mixed well and the intensity of the pink color was measured at $510 \mathrm{~nm}$ against blank. The content of flavonoid was calculated on the basis of the calibration curve of quercetin and the results were expressed as mg of quercetin equivalents per $\mathrm{g}$ of extract

\section{Total ascorbic acid}

Total ascorbic acid was determined by CUPRAC assay in $100 \mathrm{mg}$ plant sample and $5 \mathrm{ml}$ of water .The absorbance of formed bis (NC) copper ( i) chelate was measured at $450 \mathrm{~nm}$.

\section{Total tannin content}

The plant extracts are taken in $1 \mathrm{ml}$ and $4 \% 2 \mathrm{ml}$ methanol was added and measuring at $500 \mathrm{~nm}$

\section{Antioxidant Activities of the Extracts}

DPPH Radical Assay (1,1-diphenyl-2-picrylhydrazyl)

The hydrogen atom or electron donation ability of the corresponding extracts and some pure compounds was measured from the bleaching of purple coloured methanol solution of DPPH. This spectrophotometric assay uses stable radical diphenylpicrylhydrazyl (DPPH) as a reagent (Gulluce et al., 2006). Fifty micro liters of various concentrations of the extracts in methanol was added to $5 \mathrm{ml}$ of a $0.004 \%$ methanol solution of DPPH. After a $30 \mathrm{~min}$ incubation period at room temperature the absorbance was read against $\mathrm{s}$ blank at $517 \mathrm{~nm}$. Inhibition free radical DPPH in percent (I\%) was calculated in the following way: $\mathrm{I} \%=$ A blank- (A sample/A blank)x100,

Where A blank is the absorbance of the control reaction (containing all reagents except the test compound), and A sample is the absorbance of the test compound. Extract concentration form the graph plotted inhibition (IC50) was calculated from the graph plotted against extract concentration. Synthetic antioxidant reagent butylatedhyroxytoluene (BHT) was used in triplicate.

\section{Ferric Thiocyanate (FTC) Method (Govindhappan et al 2000)}

Different extracts $(4 \mathrm{mg})$ and standards $(4 \mathrm{mg}$; BHT, vitamin $\mathrm{C}$ and vitamin E) were mixed with $4 \mathrm{ml}$ of absolute ethanol, $4.1 \mathrm{ml}$ of $2.52 \%$ linoleic acid in absolute ethanol, $8 \mathrm{ml}$ of $0.02 \mathrm{M}$ phosphate buffer (pH 7.0) and $3.9 \mathrm{ml}$ of distilled water. The mixture was placed at $40^{\circ} \mathrm{C}(0.1 \mathrm{ml})$ and was then mixed with $9.7 \mathrm{ml}$ of $75 \%(\mathrm{v} / \mathrm{v})$ ethanol and 0.1 $\mathrm{ml} \mathrm{30 \%} \mathrm{ammonium} \mathrm{thiocyanate.} \mathrm{Three} \mathrm{minutes}$ after adding ferrous chloride $(0.1 \mathrm{ml}$ of $2 \times 10-2$ $M$ ferrous chloride), the absorbance was measured at $500 \mathrm{~nm}$ in a spectrophotometer. This step was repeated every $24 \mathrm{~h}$ until the control reached its maximal absorbance value. The mixture without added sample was used as a control [24]. The inhibition of lipid peroxidation (\%) was estimated by the following formula:

$\%=$ Inhibition $100 \mathrm{~A} 1 / \mathrm{A} 0 \times 100$

where $\mathrm{A} 0$ is the absorbance of the control and A1 is the absorbance of the sample extracts .

\section{Thiobarbituric Acid (TBA) Method (Govindhappan et al 2000)}

Plant Extracts $(2 \mathrm{ml})$ and standard solutions $(2 \mathrm{ml})$ on the final day (day 8) of the FTC assay were added to $1 \mathrm{ml}$ of $20 \%$ aqueous Trichloroacetic acid and $2 \mathrm{ml}$ of $0.67 \%$ aqueous Thiobarbituric acid. After boiling for $10 \mathrm{~min}$, the samples were cooled. The tubes were centrifuged at $3000 \mathrm{rpm}$ for $30 \mathrm{~min}$. Absorbance of the supernatant was evaluated at $532 \mathrm{~nm}$ in a spectrophotometer. The antioxidant activity was calculated by percentage of inhibition in this method as follows:

$\%=$ Inhibition $100 \mathrm{~A} 1 / \mathrm{A} 0 \times 100$

Where $\mathrm{A} 0$ is the absorbance of the control and $\mathrm{A} 1$ is the absorbance of the sample extracts.

\section{Free Radical Scavenging Activity}

The ability of methanol and chloroform extracts of plants to scavenge 1,1-diphenyl-2-picryl-hydrazyl (DPPH) free radicals was estimated . MC extracts (3 ml) with six different concentrations (15.62, $31.25,62.5,125,250$ and $500 \mu \mathrm{g} / \mathrm{ml})$ were mixed 
with $1 \mathrm{ml}$ of a $0.1 \mathrm{mM}$ methanol solution of DPPH. The absorbance was measured by a spectrophotometer at $517 \mathrm{~nm}$ at $30 \mathrm{~min}$ intervals against a blank (pure ethanol). The percentage of radical scavenging activity was calculated using the following formula.

Radical scavenging\%=1(A0-A1/A0x100 )

Where $\mathrm{A} 0$ is the absorbance of the control and A1 is the absorbance of the sample extracts. Lower absorbance values show higher free radical scavenging activity. Ascorbic acid was used as a reference standard in different concentrations $(1.56,3.12,6.25,12.5,25$ and $50 \mu \mathrm{g} / \mathrm{ml})$. The $50 \%$ inhibitory concentration value (IC50) is indicated as the effective concentration of the sample that is required to scavenge $50 \%$ of the DPPH free radicals.

\section{Iron Chelating Activity}

The principle is based on the formation of $\mathrm{O}$ Phenanthroline-Fe2+ complex and its disruption in the presence of chelating agents. The reaction mixture containing $1 \mathrm{ml}$ of $0.05 \% \quad \mathrm{O}$ Phenanthroline in methanol, $2 \mathrm{ml}$ ferric chloride $(200 \mu \mathrm{M})$ and $2 \mathrm{ml}$ of various concentrations ranging from 10 to $1000 \mu \mathrm{g}$ was incubated at room temperature for $10 \mathrm{~min}$ and the absorbance of the same wasmeasured at $510 \mathrm{~nm}$. EDTA was used as a classical metal chelator. The experiment was performed in triplicates.

\section{Reducing Power Method (Kumaran et al., 2007)}

$1 \mathrm{~m} 1$ of plant sample was mixed with $2.5 \mathrm{~m} 1$ phosphate buffer $(0.2 \mathrm{M}) \mathrm{pH} 6.6$ and $2.5 \mathrm{~m} 1(1 \%)$ $(\mathrm{K} 3(\mathrm{Fe}(\mathrm{CN}) \mathrm{t}$;); the mixture was incubated at room temperature for 20 minutes, after which 2.5 $\mathrm{ml}(10 \%)$ trichloroacetic acid was added. The whole mixture was then centrifuged $(650 \times \mathrm{x}$ at room temperature) for 10 minutes, $2.5 \mathrm{~m} 1$ upper layer was removed and $2.5 \mathrm{ml} \mathrm{H} 20$ and $0.5 \mathrm{ml}$ $(0.1 \%)$ Fecl2 were added. Triplicates solutions were prepared. This was allowed to stand for 30minutes the absorbance was measured at 700 $\mathrm{nm}$.

\section{Thin layer chromatography phytochemical assay}

The plant extracts were spotted onto a silica gel TLC plate (Kieselogel 60 F254 0.2 mm, Merck).

The plates were developed in ascending direction with toluene: acetone: methanol $(1: 1: 3)$ and $\mathrm{CHCl} 3$ : acetone: methanol: $\mathrm{H} 2 \mathrm{O}(1: 7: 4: 5)$ as mobile phase. Spots were visualized by UV irradiation at $366 \mathrm{~nm}$ after spraying with $\mathrm{AlCl} 3$ reagent (Harbone, 1973; Wagner et al., 1984) for phenolic/ flavonoid compounds, acidic iodinepotassium iodide for alkaloids, perchloric acid for sterols (Hara, 1963), Benedicts reagent for caumarrins and flavonoids, vanillin- $\mathrm{HCl}$ reagent for proanthocyanidins (Ribera- Gayon, 1972), and antimony (III) chloride reagent for cardiac glycoside (Wagner et al., 1984).

\section{ISOLATION AND SCREENING OF FISH PATHOGENS}

Fish samples viz., matthisankara, prawn collected from the erode fish market. Collected samples were aseptically taken to the Biotechnology lab for bacteriological examination. The chosen fish were cut down into small pieces, sterilized/washed with $70 \%$ absolute ethanol and later $\mathrm{d} 3 \mathrm{H} 2 \mathrm{O}$ (double distilled deionized water) for $5 \mathrm{~min}$ to remove excess ethanol. Washed sample products were placed on Nutrient agar (NA) medium supplemented with methyl red and crystal violet. After the incubation of 24 hours at $37^{\circ} \mathrm{C}$, the small portion of growth area were picked with sterilized loop and again streaked on the different selected medium such as Nutrient gar (NA; supplemented with crystal violet and methyl red), Macconkey agar (MA), Eosin methyleneblue (EMB) ,Blood agar(BA), Bismuth sulphate agar(BSA), Neutral red chalk lactose agar( NRCLA) and also biochemical tests respectively for the screening of single pathogen. Stock cultures were grown in Nutrient Broth at $37^{\circ} \mathrm{C}$ and stored at $-20^{\circ} \mathrm{C}$ as $60 \%$ glycerol stock before used for Antibacterial analysis.

Biochemical Tests of Isolated Pathogens
(microbiology Pelzer) 
The gram staining was aimed at differentiating gram reactions, sizes, shapes and arrangement of cells of the isolates. Various biochemical tests such as oxidase, catalase, urease, $\mathrm{H} 2 \mathrm{~S}$, citrate utilization, Voguesproskeur test were used for the confirmation of test pathogen.

\section{Sensitivity Test of Antibiotics}

Sensitivity of antibiotics against test strains was determined by filter disc diffusion method

Sensitivity was predictable with clear zone surrounding the disc. The potency of antibiotics ( 5 $\mathrm{mm}$ in diameter) per disc are as follows; Amoxicillin $(10 \mu \mathrm{g})$, Streptomycin $(10 \mu \mathrm{g})$, Tobramycin $(10 \mu \mathrm{g})$, Gentamicin $(10 \mu \mathrm{g})$, Ciprofloxacin $(5 \mu \mathrm{g})$, Sulfomethoxyzol $(25 \mu \mathrm{g})$, Tetracycline $(10 \mu \mathrm{g})$, Penicillin G $(10 \mu \mathrm{g})$, Trimethoprim $(5 \mu \mathrm{g})$, Ampicillin $(10 \mu \mathrm{g})$.

\section{Antibacterial Activity through Filter Disk Diffusion Method}

Filter disc diffusion method was used for testing of medicinal plant extracts against four bacterial fish pathogens viz., Escherichia coli, Klebsilla, Streptocoocus, Salmonella, Staphylococcusaureus , Whatman No. 1 filter paper disc (5 mmdiameter) was impregnated with crude $(10 \mu \mathrm{l})$ plant extracts was placed on Muller Hinton agar. This was previously swabbed with bacterial fish pathogens. The sterile discimpregnated with only solvents used as a negative control. All the plates were incubated at $37^{\circ} \mathrm{C}$ for 24 hours under static conditions. After 24 hours the zone of inhibition appearing aroundthe discs were measured and recorded in millimeter $(\mathrm{mm})$ diameter. Each experiment wasconducted thrice, and the mean of the results were calculated for both the test and control.

\section{Preparation of Extract and Antibacterial Activity}

The plant leaves were collected and dried. The sample was spread out during daylight hours for 5 days until it dried to brittleness. Dried peels were powdered to get 60- mesh size using a mixer grinder. Thirty grams of powdered peel was extracted with different solvents like Hexane, ethanol and methanol with occasional shaking for 3 days at room temperature. The extracts were filtered, concentrated and dried at 50oC and the weight of each residue was recorded.

(Shiv Shanker Gautam et al., 2011)

\section{Minimum Bactericidal Concentration}

The MBC was performed to test the antimicrobial activity of active extract using tube dilution method. The MBC was defined as lowest concentration able to kill any microbe. Dilutions of the plant extract were prepared in sterile nutrient broth to get a final concentration of $2 \mathrm{mg}$, $4 \mathrm{mg}, 8 \mathrm{mg}, 16 \mathrm{mg}, 32 \mathrm{mg}$ and $64 \mathrm{mg} / \mathrm{ml}$ respectively (Mathuret al., 1996). To each of these dilutions, a loop full of STEC culture adjusted to 0.5 Mac Farlandstandards, was inoculated and all the tubes were incubated at $37 \mathrm{oC}$ for $24 \mathrm{hrs}$. After incubation, loopfull from each tube was inoculated onto nutrient agar plates. The plate without growth was recorded as MBC.

\section{Preparation of agar wells for different solvent extracts}

$5 \mathrm{~mm}$ borer was used to prepare wells in agar. Four wells per plate at four equidistant corners were made. A $50 \mu \mathrm{l}$ solvent extract was transferred by micropipette per well. Plates were Immediately kept at $4 \mathrm{oC}$ in refrigerator for $1 \mathrm{~h}$ for the diffusion of extract.And then shifted to $350 \mathrm{C}$ or $.5 \mathrm{oC}$ in incubator. Zone of inhibition was measured after $24 \mathrm{~h}$ of incubation.For each bacterial strain, controls were maintained in which pure solvents were used instead of the extract. The control zones were subtracted from the test zones and the resulting zone diameter is obtained.

\section{Thin Layer Chromatography and TLC Bio autography Analysis}

The methanol extracts were applied at $2.5 \mathrm{~cm}$ from the base of silica gel G TLC plate. The TLC plates were developed with ethyl acetate: methanol: water (81:11:8) and were run in duplicate. $5 \%$ ferric chloride reagent was sprayed and the chromatogram was observed. The second set of chromatogram, developed as described above in TLC plates. Which was not subjected to chemical treatment for observing spots was loaded with the inoculum of test organisms in molten Mueller Hinton Agar, over the TLC plates. After the solidification of the medium, the TLC plate 


\section{JMSCR Vol||3||Issue||10||Page 7778-7799||October}

was incubated overnight at $37 \mathrm{oC}$. Subsequently, bioautogram developed was sprayed with $1 \%$ aqueous solution of $2,3,5$, triphenyl tetrazolium chloride (TTC) and incubated at 37C for $4 \mathrm{~h}$.
Inhibition zone indicated the presence of active compounds (Anjanaet al., 2010). Ellagic acid and the antibiotic rifampin were used as controls.

\section{TOTAL ASCORBIC ACIDTABLE 2}

\begin{tabular}{|c|c|c|c|c|c|}
\hline Plants extracts (m) & \multirow{6}{*}{$\begin{array}{l}\text { OD } \\
\text { At } \\
\mathbf{4 5 0} \\
\mathbf{n m}\end{array}$} & Capacity & Plant extracts $(\mathrm{H})$ & \multirow{6}{*}{$\begin{array}{l}\text { OD } \\
\text { At } \\
\mathbf{4 5 0} \\
\mathbf{n m}\end{array}$} & Capacity \\
\hline Carciya papaya & & 0.837 & Carciya papaya & & 0.868 \\
\hline Indian gooseberry & & 0.506 & Indian gooseberry & & 0.050 \\
\hline Menthaspicata & & 0.461 & Menthaspicata & & 0.061 \\
\hline pomengrate & & 0.217 & pomengrate & & 0.167 \\
\hline Solanum nigrum & & 0.096 & Solanum nigrum & & 0.016 \\
\hline
\end{tabular}

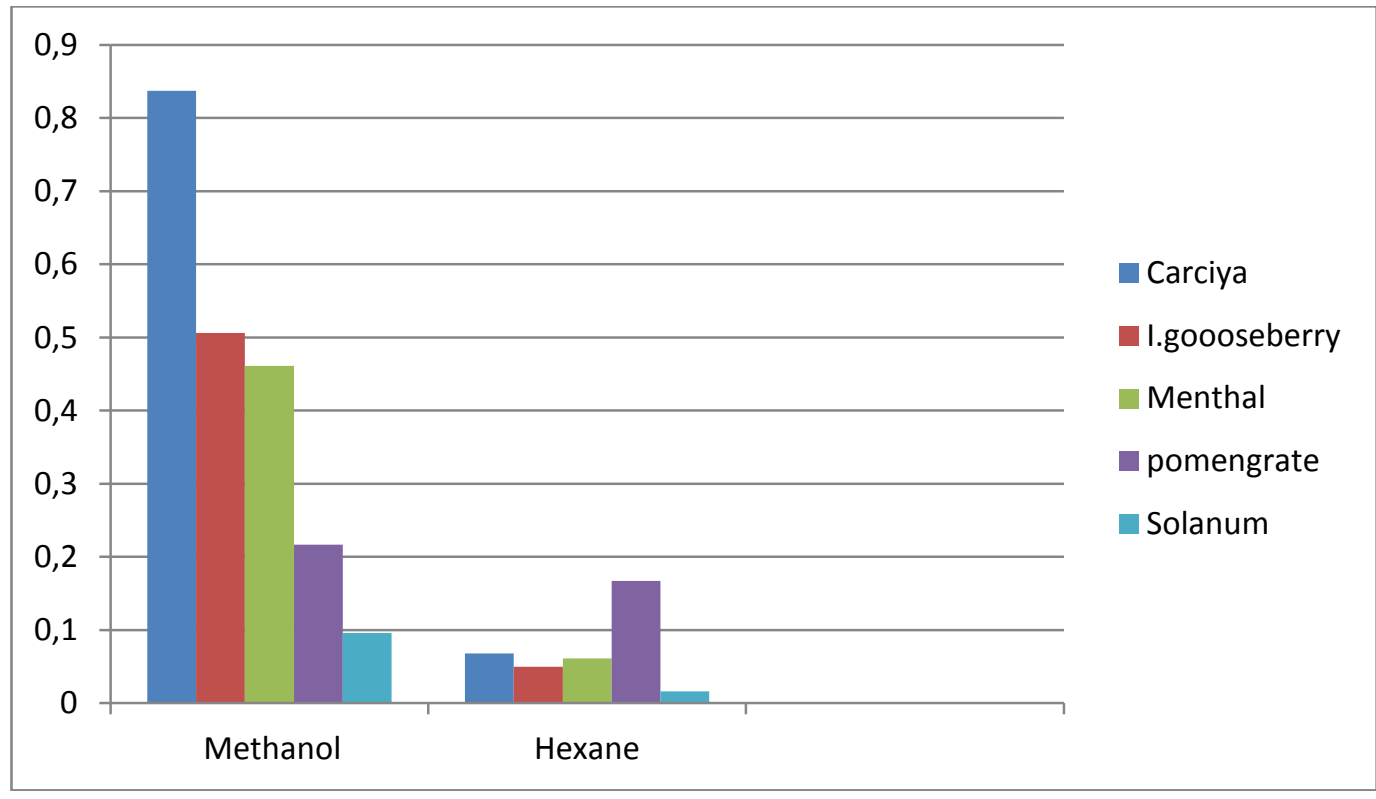

TOTAL TANIN CONTENT TABLE 3

\begin{tabular}{|l|l|l|l|l|l|l|}
\hline $\begin{array}{l}\text { Plant } \\
\text { extracts }\end{array}$ & \multirow{2}{*}{$\begin{array}{l}\text { OD at } \\
\text { 500nm }\end{array}$} & $\begin{array}{l}\text { Carciya } \\
\text { papaya }\end{array}$ & $\begin{array}{l}\text { Indian } \\
\text { gooseberry }\end{array}$ & $\begin{array}{l}\text { Mentha } \\
\text { spicata }\end{array}$ & pomengrate & Solanumnigrum \\
\cline { 1 - 5 } Methanol & & 1.963 & 1.113 & 1.993 & 1.625 & 1.967 \\
\cline { 1 - 5 } & & 0.876 & 0.298 & 0.783 & 0.257 & 0.235 \\
\hline
\end{tabular}




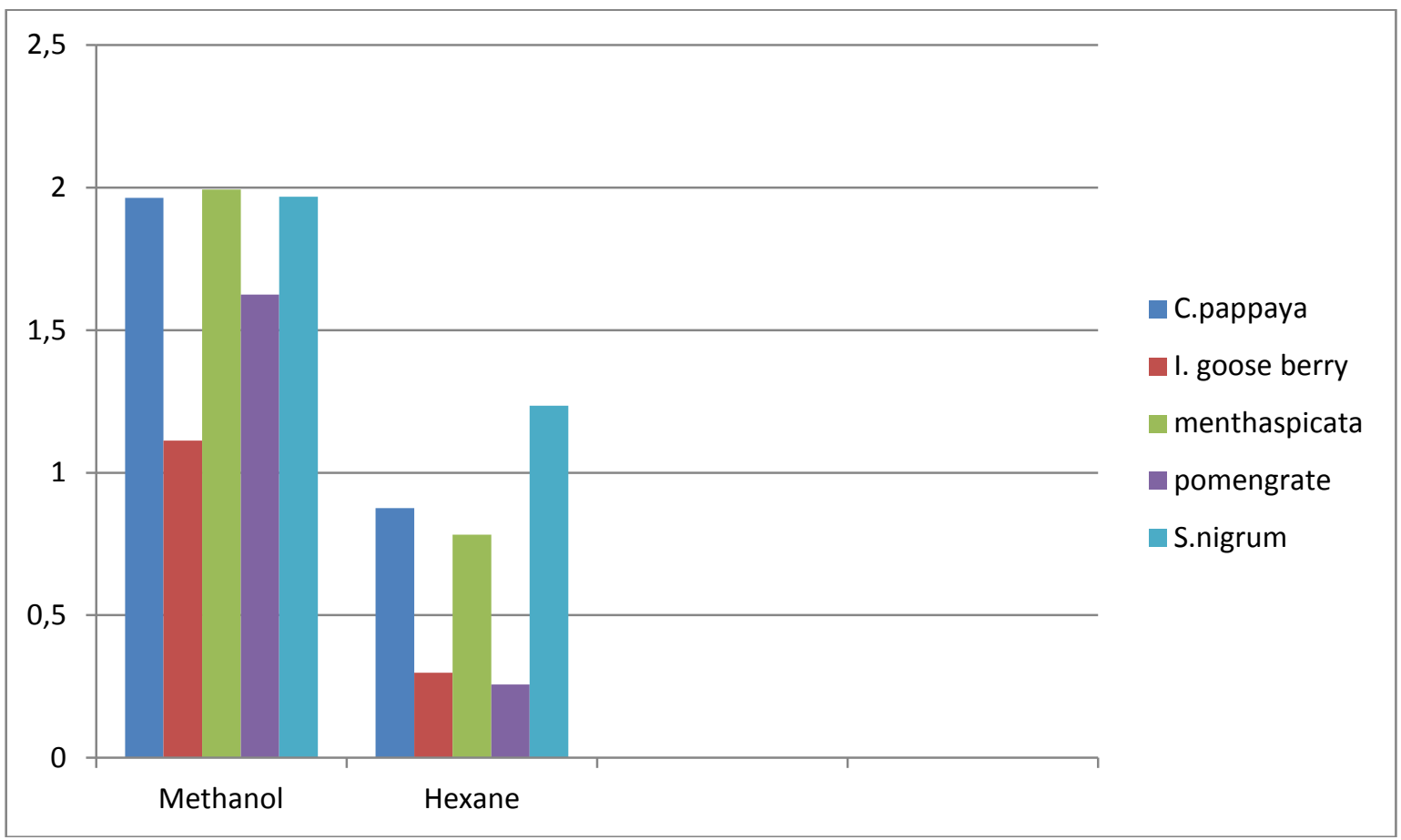

TOTAL TANIN CONTENT TABLE 3

\begin{tabular}{|c|c|c|c|c|c|c|}
\hline $\begin{array}{l}\text { Plant } \\
\text { extracts }\end{array}$ & OD at & $\begin{array}{l}\text { Carciya } \\
\text { papaya }\end{array}$ & $\begin{array}{l}\text { Indian } \\
\text { gooseberry }\end{array}$ & $\begin{array}{l}\text { Mentha } \\
\text { spicata }\end{array}$ & pomengrate & $\begin{array}{l}\text { Solanum } \\
\text { nigrum }\end{array}$ \\
\hline Methanol & & 1.963 & 1.113 & 1.993 & 1.625 & 1.967 \\
\hline Hexane & & 0.876 & 0.298 & 0.783 & 0.257 & 0.235 \\
\hline
\end{tabular}

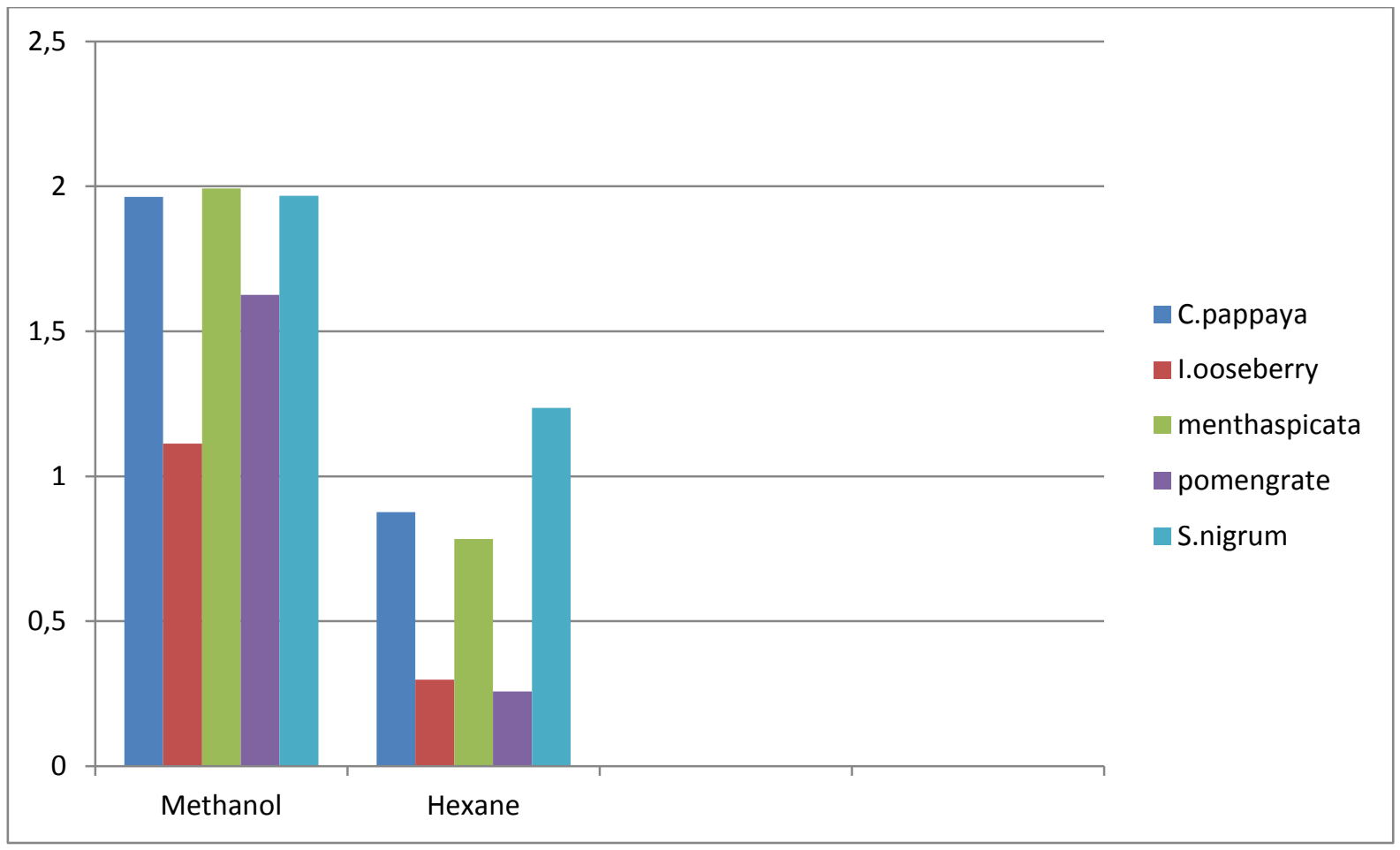


JMSCR Vol||3||Issue||10||Page 7778-7799||October

TOTAL PHENOL CONCENTRATION TABLE 4

\begin{tabular}{|l|l|l|l|l|l|l|}
\hline $\begin{array}{l}\text { Plant } \\
\text { extracts }\end{array}$ & \multirow{2}{*}{$\begin{array}{l}\text { ODat } \\
760 \mathrm{~nm}\end{array}$} & $\begin{array}{l}\text { Carciya } \\
\text { papaya }\end{array}$ & $\begin{array}{l}\text { Indian } \\
\text { gooseberry }\end{array}$ & $\begin{array}{l}\text { Mentha } \\
\text { spicata }\end{array}$ & pomengrate & $\begin{array}{l}\text { Solanum } \\
\text { nigrum }\end{array}$ \\
\cline { 3 - 7 } Methanol & & 1.180 & 0.151 & 1.123 & 0.293 & 0.762 \\
\cline { 3 - 7 } & & 0.076 & 0.486 & 0.234 & 0.598 & 0.670 \\
\hline
\end{tabular}

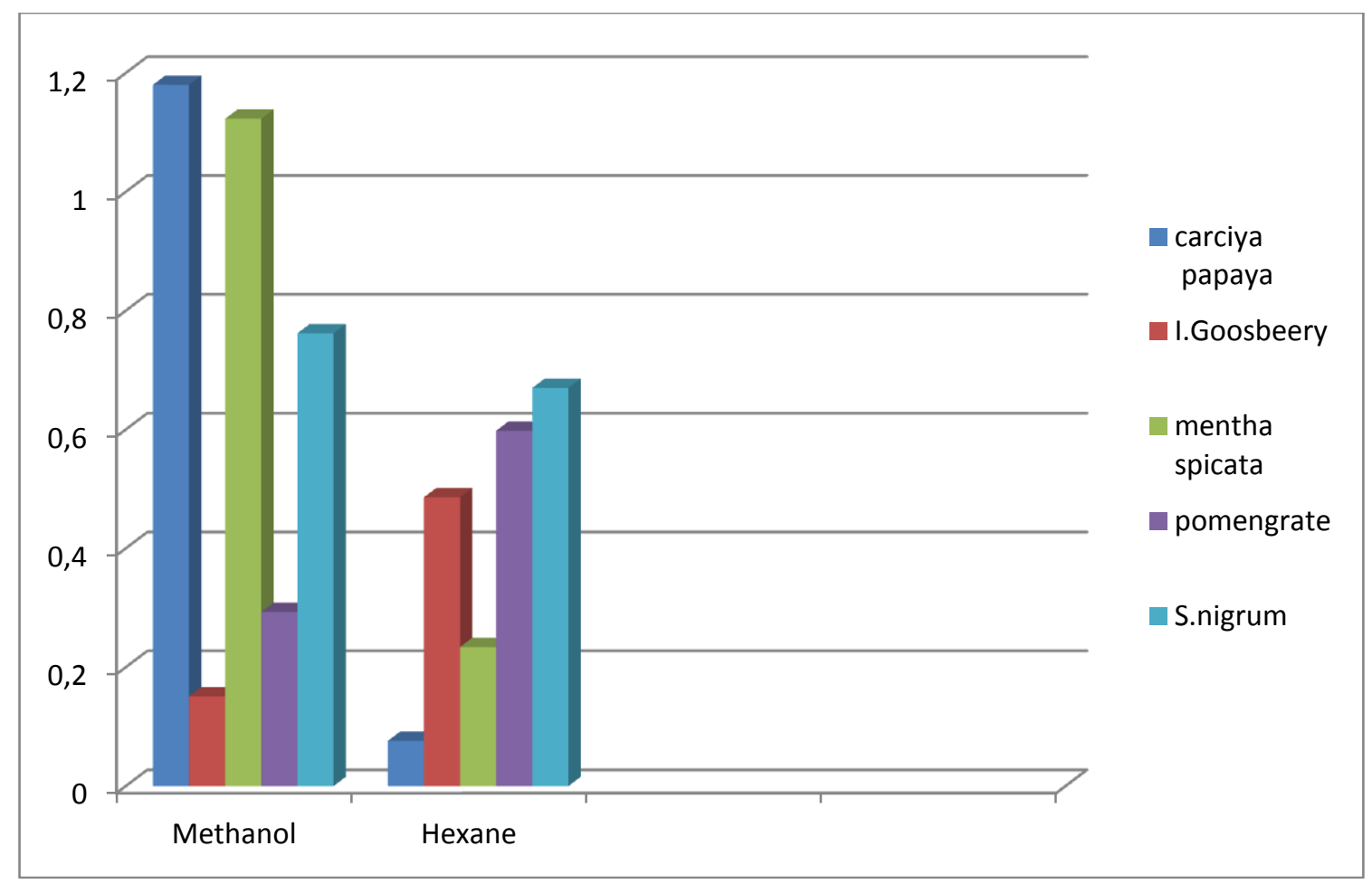

TOTAL FLAVANOID DETERMINATION TABLE 5

\begin{tabular}{|l|l|l|l|l|l|}
\hline $\begin{array}{l}\text { Plant } \\
\text { extracts }\end{array}$ & C.papaya & $\begin{array}{l}\text { Indian } \\
\text { gooseberry }\end{array}$ & Menthaspicata & pomengrate & $\begin{array}{l}\text { Solanum } \\
\text { nigrum }\end{array}$ \\
\hline Methanol & 1.419 & 0.138 & 0.702 & 1.639 & 0.344 \\
\hline hexane & 0.782 & 0.524 & 0.796 & 0.684 & 0.486 \\
\hline
\end{tabular}




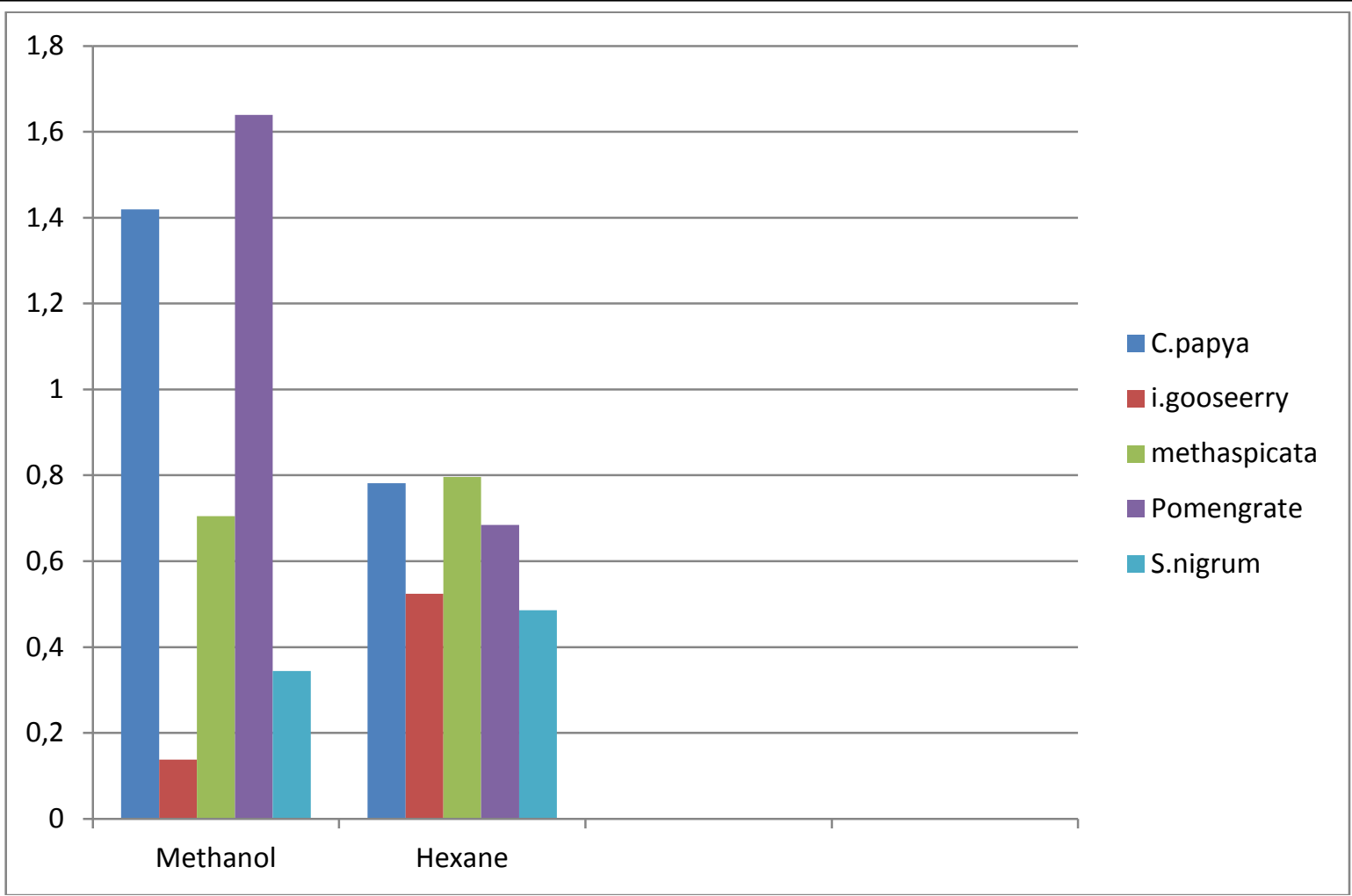

TOTAL ANTIOXIDANT CAPACITY TABLE6

\begin{tabular}{|l|l|l|l|l|l|l|}
\hline $\begin{array}{l}\text { Plant } \\
\text { extracts(m) }\end{array}$ & $\begin{array}{l}\text { OD at } \\
\text { 595 nm } \\
\text { BHT }\end{array}$ & $\begin{array}{l}\text { \%of } \\
\text { inhibitio } \\
\text { n } \\
\text { 100A1x } \\
\text { A0/100 }\end{array}$ & $\begin{array}{l}\text { Vitamin } \\
\text { C OD at } \\
595 \text { nm }\end{array}$ & $\begin{array}{l}\text { \%of inhibition } \\
\text { 100A1xA0/100 }\end{array}$ & $\begin{array}{l}\text { Vitamin } \\
\text { E OD at } \\
595 \text { nm }\end{array}$ & $\begin{array}{l}\text { \%of } \\
\text { inhibition } \\
\text { 100A1xA0/ } \\
100\end{array}$ \\
\hline C.papaya & 1.973 & 1.152 & 0.319 & 0.324 & 1.734 & 1.469 \\
\hline I.gooseberry & $\mathbf{0 . 8 7 1}$ & $\mathbf{0 . 5 0 8}$ & $\mathbf{0 . 2 6 7}$ & $\mathbf{0 . 2 7 1 1}$ & $\mathbf{0 . 3 1 1}$ & $\mathbf{0 . 2 6 0}$ \\
\hline $\begin{array}{l}\text { Mentha } \\
\text { spicata }\end{array}$ & 1.37 & $\mathbf{0 . 8 0 2 5}$ & $\mathbf{0 . 7 2 1}$ & $\mathbf{0 . 7 9 3 6}$ & 1.739 & 1.473 \\
\hline Pomengrate & 1.513 & $\mathbf{0 . 8 8 3 7}$ & $\mathbf{0 . 6 4 3}$ & $\mathbf{0 . 6 5 3}$ & 1.938 & 1.642 \\
\hline S.nigrum & 1.03 & $\mathbf{0 . 5 4 1}$ & $\mathbf{0 . 3 5 1}$ & $\mathbf{0 . 3 5 6 7}$ & 1.773 & 1.502 \\
\hline
\end{tabular}




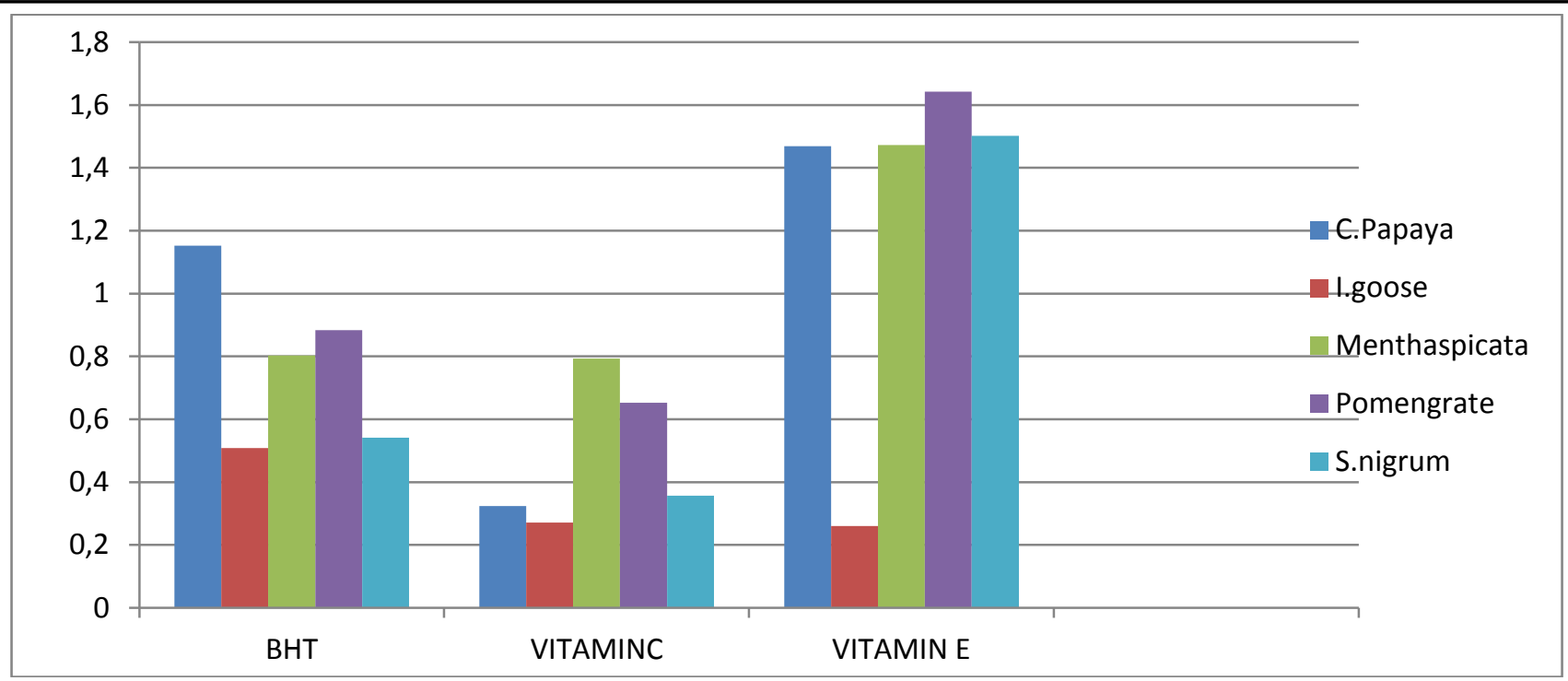

$\%$ inhibition of total antioxidant

\section{HYDROXYL RADICAL SCAVENGING ACTIVITY TABLE 7}

\begin{tabular}{|l|l|l|l|l|l|}
\hline Extracts & C.papaya & I.gooseberry & Menthaspicata & pomengrate & Solanumnigrum \\
\hline $20 \mu \mathrm{l}$ & 4.63 & 2.69 & 8.51 & 8.12 & 1.62 \\
\hline $40 \mu \mathrm{l}$ & 5.26 & 9.54 & $6.45 \pm 0.01$ & 6.45 & 5.40 \\
\hline $80 \mu \mathrm{l}$ & 9.14 & 7.36 & 4.75 & 4.46 & 7.36 \\
\hline $160 \mu \mathrm{l}$ & 4.24 & 5.66 & 4.48 & 3.88 & 6.52 \\
\hline
\end{tabular}

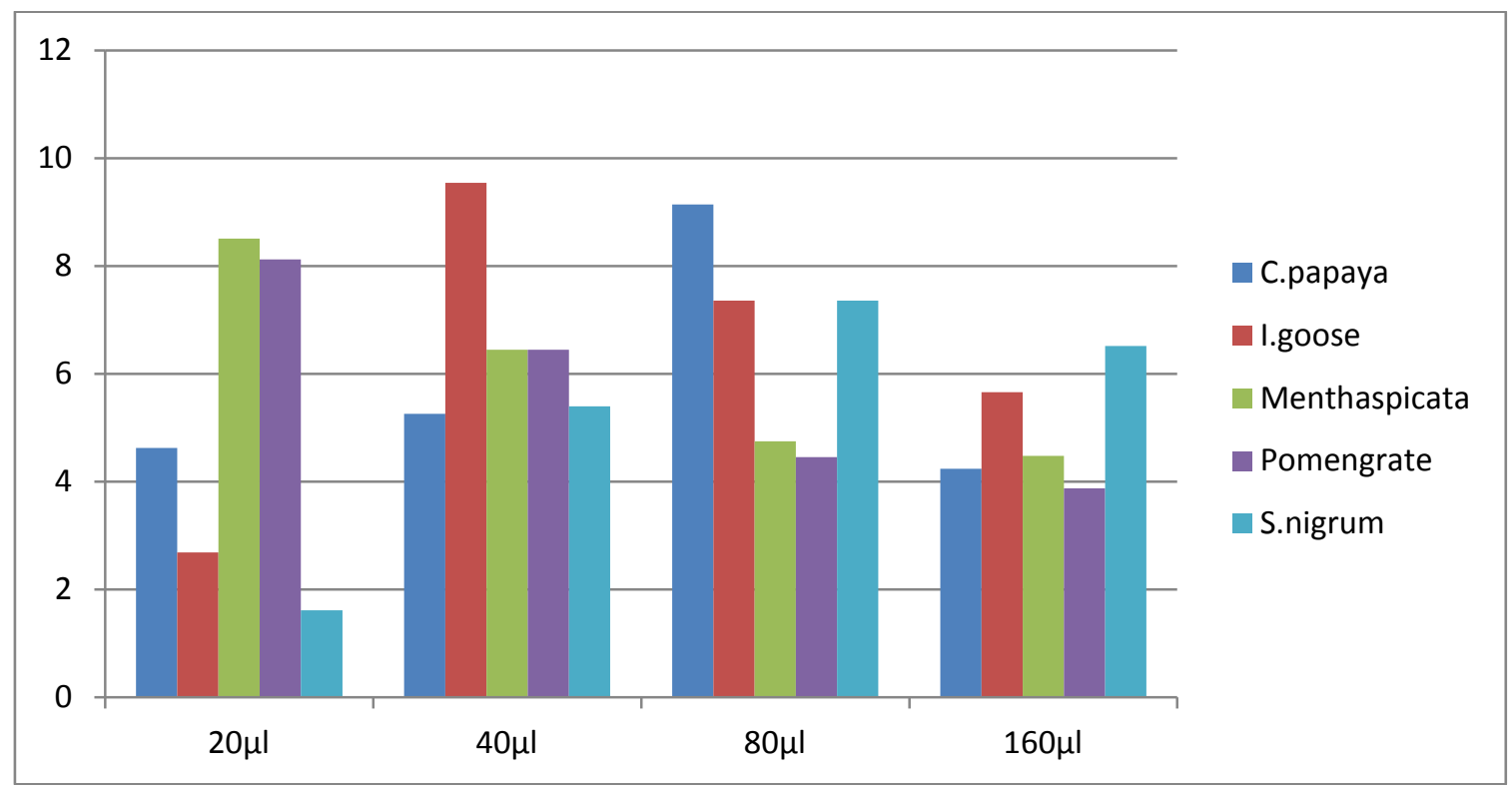

\% Inhibition hydroxyl radical scavenging 
JMSCR VoI||3||Issue||10||Page 7778-7799||October

ANTIOXIDANT ACTIVITY TABLE 8
\begin{tabular}{|l|l|l|l|l|l|}
\hline Extracts & C.papaya & $\begin{array}{l}\text { Indian } \\
\text { gooseberry }\end{array}$ & Menthaspicata & pomengrate & Solanumnigrum \\
\hline $20 \mu \mathrm{l}$ & 3.52 & 9.12 & 6.81 & 6.97 & 1.16 \\
\hline $40 \mu \mathrm{l}$ & 4.45 & 3.47 & 6.99 & 2.17 & 0.66 \\
\hline $80 \mu \mathrm{l}$ & 4.0. & 5.29 & 4.65 & 5.47 & 6.23 \\
\hline $160 \mu \mathrm{l}$ & 6.97 & 6.66 & 6.27 & 4.37 & 2.46 \\
\hline
\end{tabular}

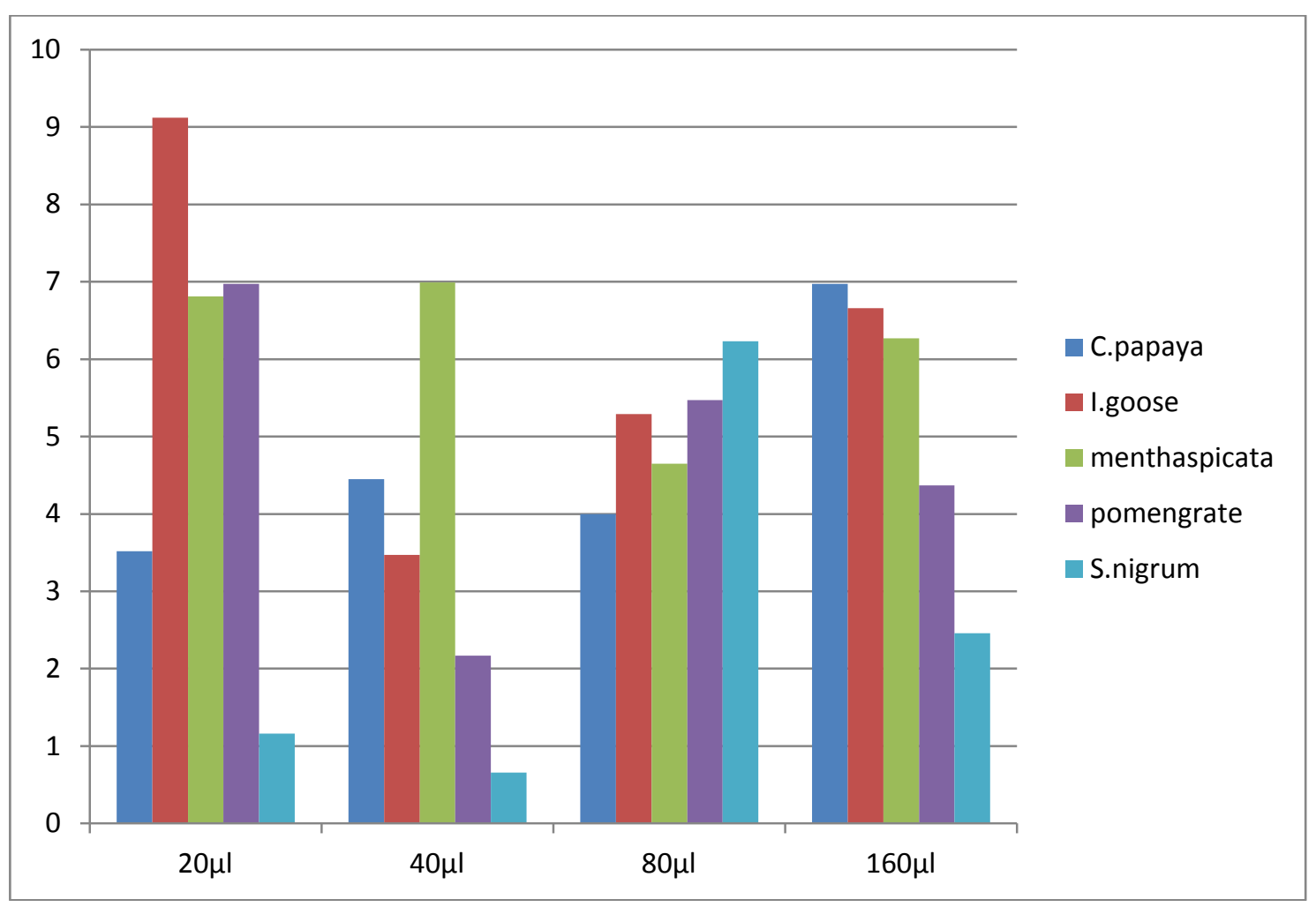

\% inhibition of DPPH radical

IORN CHELATING ACTIVITY TABLE 9

\begin{tabular}{|l|l|}
\hline Name of the plant & $\begin{array}{l}\text { Fe2+ chelating activity } \\
\text { (IC50 } \mathbf{~ m g} / \mathbf{m l} \text { ) }\end{array}$ \\
\hline carciya papaya & 8.2 \\
\hline I.gooseberry & $2.50 \pm 0.01$ \\
\hline Menthaspicata & $4.11 \pm 0.01$ \\
\hline Pomengrate & $6.40 \pm 0.02$ \\
\hline Solanum nigrum & $1.83 \pm 0.16$ \\
\hline
\end{tabular}




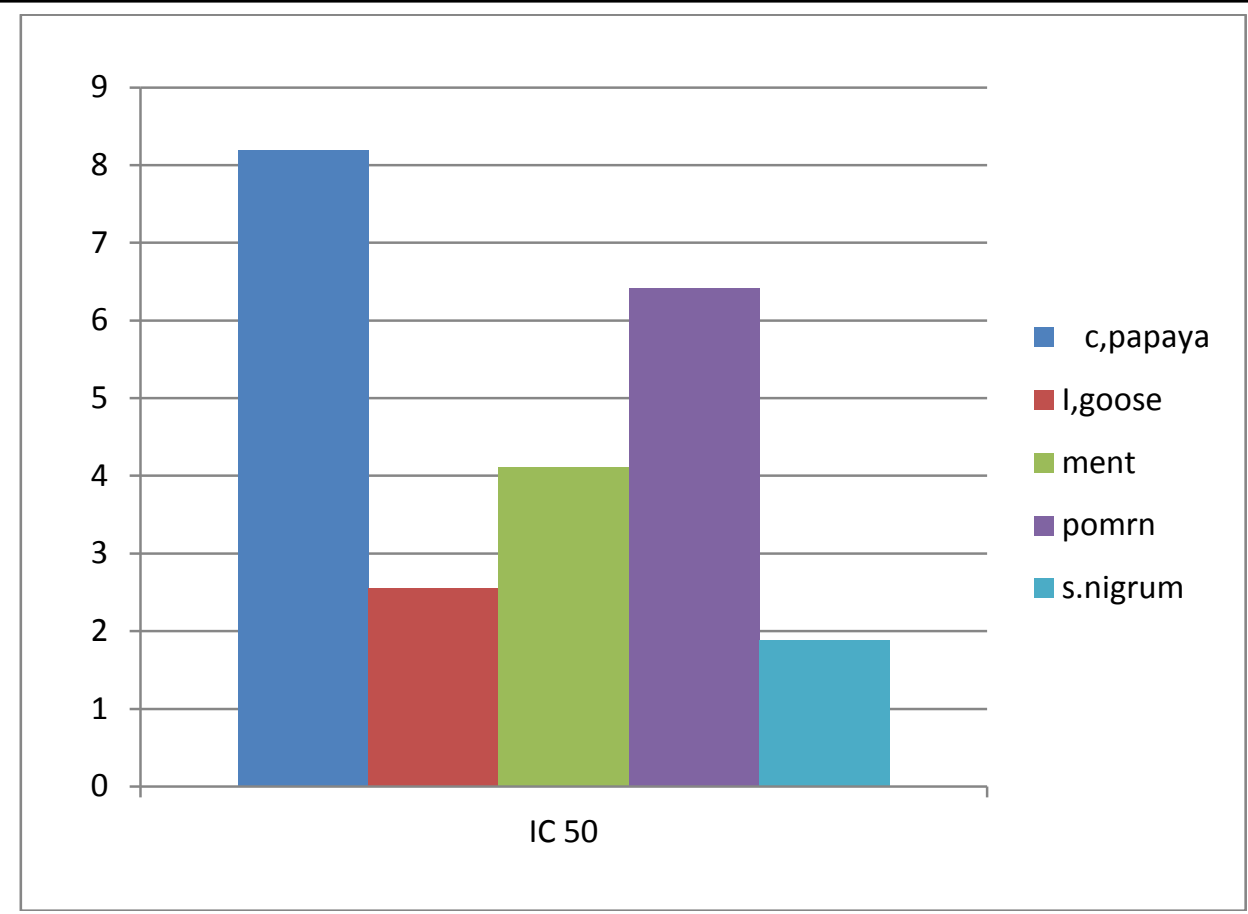

$\%$ inhibition of Iorn chelating activity

REDUCING POWER ASSAY TABLE 10

\begin{tabular}{|l|l|l|l|l|l|}
\hline $\begin{array}{l}\text { Plant } \\
\text { extracts/ } \boldsymbol{\mu l}\end{array}$ & $\begin{array}{l}\text { Carciya } \\
\text { papaya }\end{array}$ & I.gooseberry & Menthaspicata & Pomengrate & S.nigrum \\
\hline $25 \mu \mathrm{l}$ & 0.487 & 0.335 & 0.84 & 0.53 & 0.34 \\
\hline $50 \mu \mathrm{l}$ & 0.501 & 0.625 & 0.89 & 0.65 & 0.51 \\
\hline $75 \mu \mathrm{l}$ & 0.964 & 0.843 & 1.34 & 0.846 & 0.934 \\
\hline
\end{tabular}

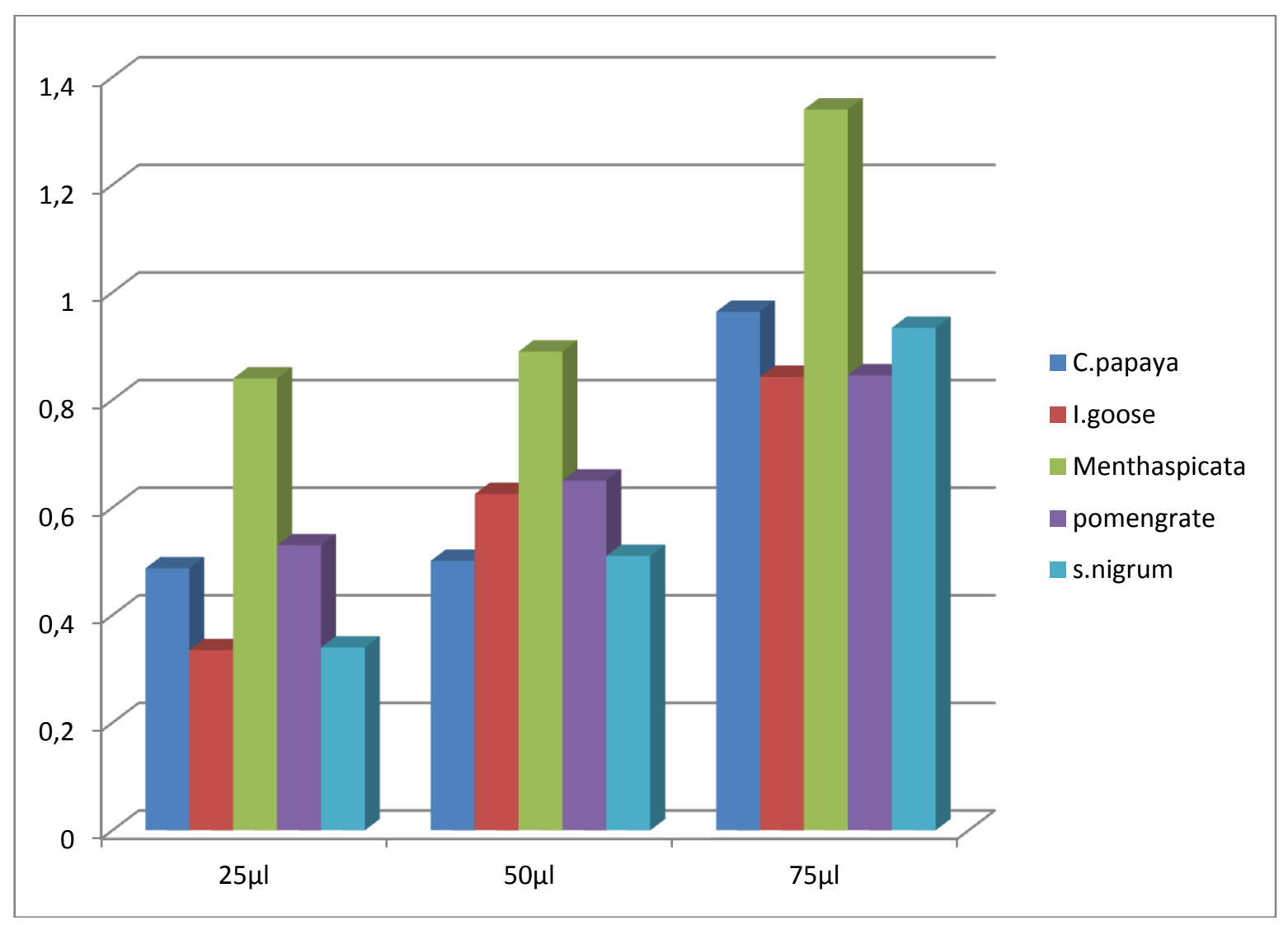


BIOCHEMICAL TEST/CARBOHYDRATE FERMENTATION TEST /DIFFERENTIAL MEDIA TABLE 11

\begin{tabular}{|c|c|c|c|c|c|c|c|}
\hline S.NO & $\begin{array}{l}\text { Biochemical } \\
\text { /differential } \\
\text { media }\end{array}$ & $\begin{array}{l}\text { MATTHI } \\
\text { A } \\
\text { May be } \\
\text { E.coli }\end{array}$ & $\begin{array}{l}\text { MATTHI } \\
\text { B }\end{array}$ & $\begin{array}{l}\text { PRAWN } \\
\text { A May be } \\
\text { Klebsilla }\end{array}$ & $\begin{array}{l}\text { PRAWN } \\
\text { B May be } \\
\text { salmonella }\end{array}$ & $\begin{array}{l}\text { SANKARA } \\
\text { A May be } \\
\text { saphylococcus }\end{array}$ & $\begin{array}{l}\text { SANKARA } \\
\text { B May be } \\
\text { streptococcus }\end{array}$ \\
\hline 1. & Indole & $\mathrm{P}+$ & $\mathrm{P}+$ & N- & $\mathrm{N}-$ & $\mathrm{N}-$ & $\mathrm{N}-$ \\
\hline 2. & MR & $\mathrm{P}+$ & $\mathrm{P}+$ & $\mathrm{N}-$ & $\mathrm{P}+$ & $\mathrm{P}+$ & $\mathrm{P}+$ \\
\hline 3. & VP & $\mathrm{N}-$ & $\mathrm{N}-$ & $\mathrm{N}-$ & $\mathrm{N}-$ & $\mathrm{P}+$ & N- \\
\hline 4 & CITRATE & $\mathrm{N}-$ & $\mathrm{N}-$ & $\mathrm{P}+$ & $\mathrm{N}-$ & $\mathrm{N}-$ & $\mathrm{P}+$ \\
\hline .5 . & GLUCOSE & $\mathrm{P}+$ & $\mathrm{P}+$ & $\mathrm{P}+$ & N- & $\mathrm{N}-$ & ACID/P+ \\
\hline 6. & LACTOSE & $\mathrm{P}+$ & $\mathrm{P}+$ & $\mathrm{P}+$ & $\mathrm{N}-$ & $\mathrm{N}-$ & $\mathrm{ACID} / \mathrm{P}+$ \\
\hline 7. & MANITOL & $\mathrm{N}-$ & $\mathrm{P}+$ & $\mathrm{P}+$ & $\mathrm{P}+$ & A/GAS & $\mathrm{ACID} / \mathrm{P}+$ \\
\hline 8. & SUCROSE & $\mathrm{P}+$ & $\mathrm{N}-$ & $\mathrm{P}+$ & $\mathrm{P}+$ & A/NO GAS & $\mathrm{ACID} / \mathrm{P}+$ \\
\hline 9. & CATALASE & $\mathrm{P}+$ & N- & $\mathrm{P}+-$ & $\mathrm{P}+$ & $\mathrm{P}+$ & $\mathrm{N}-$ \\
\hline 10 & OXIDASE & $\mathrm{N}-$ & $\mathrm{N}-$ & $\mathrm{N}-$ & $\mathrm{N}-$ & $\mathrm{P}+$ & N- \\
\hline 11. & NITRATE & $\mathrm{P}+$ & $\mathrm{P}+$ & $\mathrm{P}+$ & $\mathrm{N}-$ & $\mathrm{P}+$ & N- \\
\hline 12 & $\mathrm{H} 2 \mathrm{~S}$ & $\mathrm{~N}-$ & $\mathrm{N}-$ & N- & N- & N- & N- \\
\hline 13 & UREASE & $\mathrm{P}+$ & $\mathrm{P}+$ & N- & $\mathrm{N}-$ & $\mathrm{N}-$ & $\mathrm{N}-$ \\
\hline .14 & TSI & $\mathrm{A} / \mathrm{A}$ & $\mathrm{A} / \mathrm{A}$ & $\mathrm{A} / \mathrm{G}$ & $\mathrm{A} / \mathrm{A}$ & $\mathrm{A} / \mathrm{A}$ & AL/AL \\
\hline 15. & STARCH & $\mathrm{N}-$ & $\mathrm{P}+$ & $\mathrm{P}+$ & $\mathrm{N}-$ & $\mathrm{N}-$ & $\mathrm{N}-$ \\
\hline 16 & CASEIN & $\mathrm{N}-$ & $\mathrm{N}-$ & $\mathrm{P}+$ & $\mathrm{N}$ & N- & N- \\
\hline 17 & SIM AGAR & $\mathrm{N}-$ & $\mathrm{N}-$ & $\mathrm{N}-$ & $\mathrm{P}+$ & $\mathrm{P}+$ & $\mathrm{P}+$ \\
\hline 18 & DIFFER & ENTIAL M & EDIA & & & & \\
\hline 19 & EMB & $\begin{array}{l}\text { Greenic } \\
\text { metallic } \\
\text { sheen } \\
\text { colony }\end{array}$ & $\begin{array}{l}\text { Greenic } \\
\text { metallic } \\
\text { sheen } \\
\text { colony }\end{array}$ & $\begin{array}{l}\text { Pink } \\
\text { colour } \\
\text { colony }\end{array}$ & $\begin{array}{l}\text { Colour } \\
\text { less } \\
\text { colony }\end{array}$ & $\begin{array}{l}\text { Pink colours } \\
\text { colony }\end{array}$ & $\begin{array}{l}\text { Pink colour } \\
\text { colony }\end{array}$ \\
\hline 20 & MACCONKEY & $\begin{array}{l}\text { Pink } \\
\text { colourless } \\
\text { colony }\end{array}$ & $\begin{array}{l}\text { Pink } \\
\text { colourless } \\
\text { colony }\end{array}$ & $\begin{array}{l}\text { Colourless } \\
\text { colony }\end{array}$ & $\begin{array}{l}\text { Pink } \\
\text { colourless } \\
\text { colony }\end{array}$ & $\begin{array}{l}\text { Pink colour } \\
\text { colony }\end{array}$ & $\begin{array}{l}\text { Pink Colour } \\
\text { colony }\end{array}$ \\
\hline 21 & $\begin{array}{l}\text { BLOOD } \\
\text { AGAR }\end{array}$ & no & no & no & no & $\begin{array}{l}\text { Bete } \\
\text { hemolysis } \\
\text { occur }\end{array}$ & $\begin{array}{l}\text { Alpha } \\
\text { hemolysis } \\
\text { occur }\end{array}$ \\
\hline 22 & $\begin{array}{l}\text { MANNITOL } \\
\text { SALT }\end{array}$ & no & no & no & $\begin{array}{l}\text { colour } \\
\text { less } \\
\text { colony }\end{array}$ & $\begin{array}{l}\text { Pink colour } \\
\text { colony }\end{array}$ & $\begin{array}{l}\text { Golden } \\
\text { colour } \\
\text { colony } \\
\end{array}$ \\
\hline 23 & BISMUTH & no & no & no & $\begin{array}{l}\text { Black } \\
\text { colour } \\
\text { colony }\end{array}$ & no & $\begin{array}{l}\text { Black colour } \\
\text { colony }\end{array}$ \\
\hline 24 & $\begin{array}{l}\text { NEUTRAL } \\
\text { RED }\end{array}$ & $\begin{array}{l}\text { Pink } \\
\text { colour } \\
\text { colony }\end{array}$ & $\begin{array}{l}\text { Pink } \\
\text { colour } \\
\text { colony }\end{array}$ & $\begin{array}{l}\text { Light pink } \\
\text { colour } \\
\text { colony }\end{array}$ & no & $\begin{array}{l}\text { pink colour } \\
\text { colony }\end{array}$ & $\begin{array}{l}\text { pink colour } \\
\text { colony }\end{array}$ \\
\hline
\end{tabular}

A/A-Acid butt alkaline slant A/G- Alkaline butt gas production N- Negative P+ Positive 
ANTIBIOTIC SENSITIVITY TEST TABLE12

\begin{tabular}{|l|l|l|l|l|l|l|}
\hline Organisms & Ampicillin & chloromphenicol & pencillin & streptomycin & rafomycin & kanamycin \\
\hline E.coli & $18 \pm 1$ & $21 \pm 2$ & $6 \pm 1$ & $10 \pm 3$ & $10 \pm 1$ & $25 \pm 1$ \\
\hline Klebsilla & $12 \pm 1$ & $35 \pm 1$ & $13 \pm 1$ & $20 \pm 1$ & $6 \pm 1$ & $20 \pm 1$ \\
\hline Salmonella & No & $28 \pm 1$ & $20 \pm 1$ & $25 \pm 1$ & $5 \pm 1$ & $15 \pm 1$ \\
\hline Streptococcus & $\mathbf{8} \pm 1$ & $30 \pm 2$ & $20 \pm 2$ & $20 \pm 2$ & $12 \pm 1$ & $20 \pm 1$ \\
\hline staphylococcus & No & $29 \pm 1$ & $10 \pm 3$ & $10 \pm 2$ & $10 \pm 1$ & $23 \pm 2$ \\
\hline
\end{tabular}

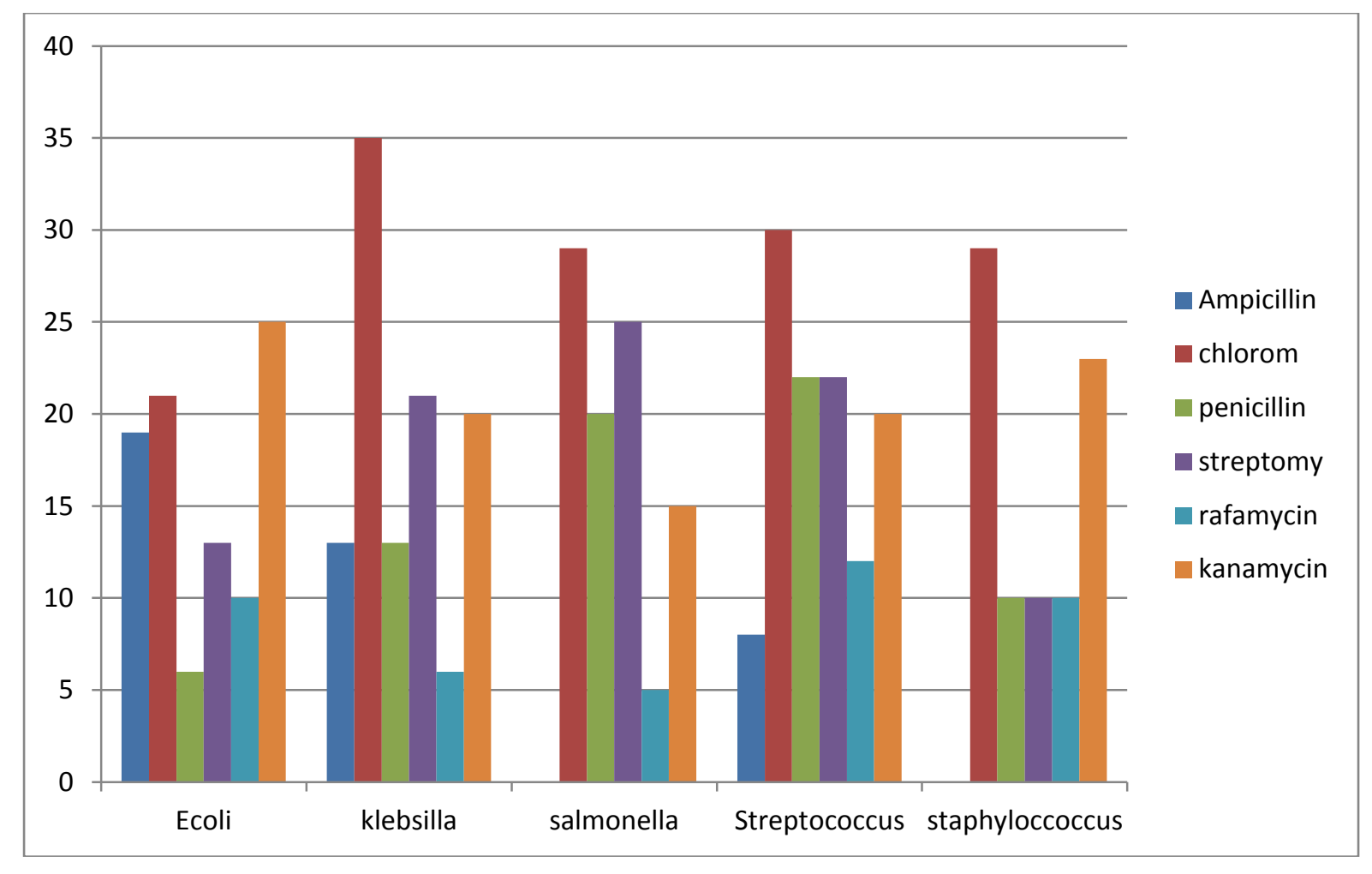

$\%$ inhibition of microorganisms

\section{ANTIBACTERIAL ACTIVITY THROUGH DISK DIFFUSION METHOD TABLE 13}

\begin{tabular}{|l|l|l|l|l|l|}
\hline $\begin{array}{l}\text { Plant } \\
\text { extraction }\end{array}$ & E.coli & klebsilla & salmonella & streptococcus & Staphylococcus \\
\hline C.papaya & No & $15 \pm 1$ & $8 \pm 3$ & 9 & 13 \\
\hline I.gooseberry & 13 & 10 & 12 & 16 & $6 \pm 3$ \\
\hline Menthaspicata & No & 11 & 15 & $15 \pm 1$ & 11 \\
\hline Pomengrate & 14 & 20 & 21 & 17 & 18 \\
\hline s.nigrum & $15 \pm 1$ & 10 & 18 & No & $12 \pm 1$ \\
\hline
\end{tabular}




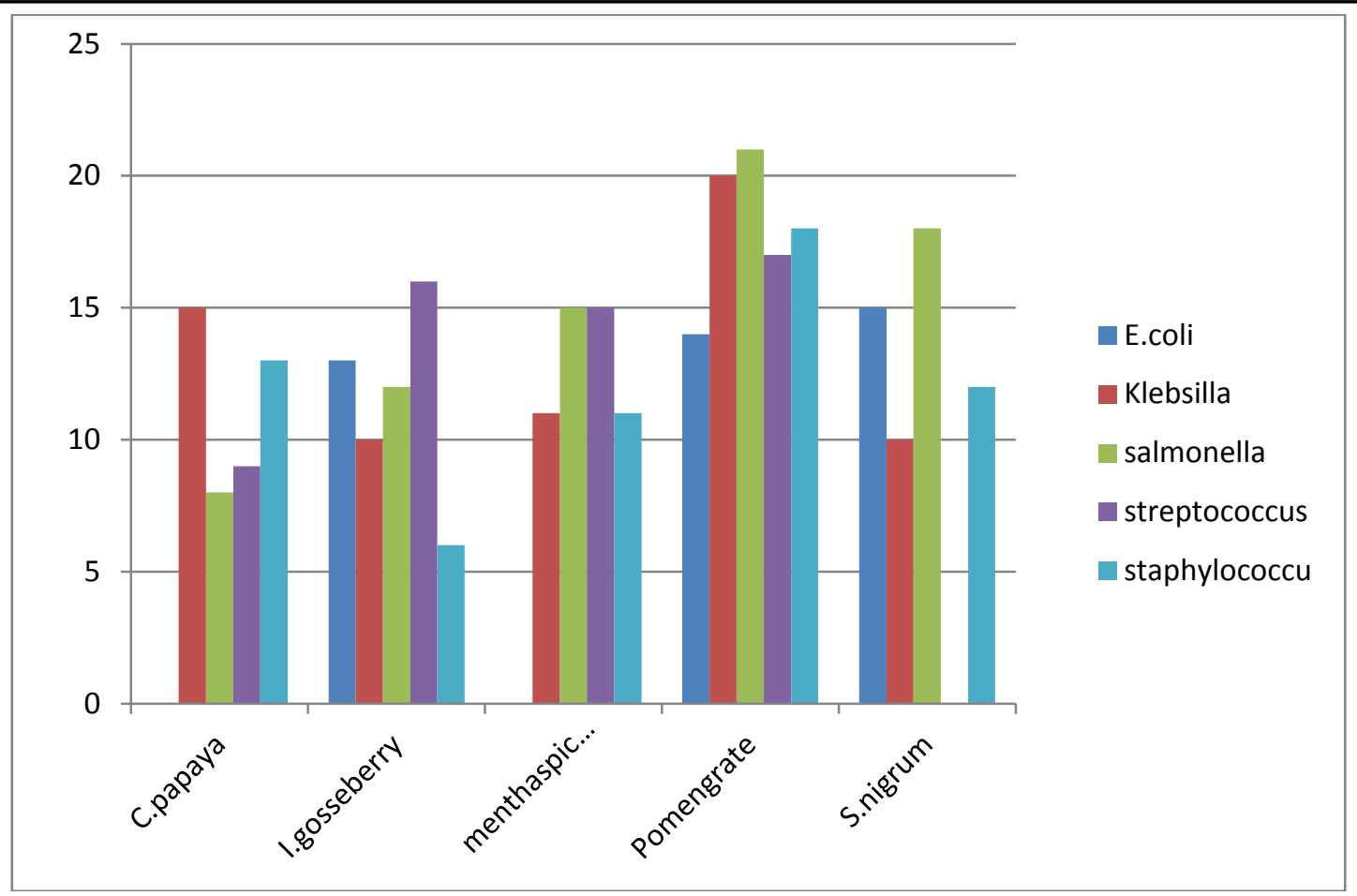

\section{PREPERATION OF AGAR WELLS FOR DIFFERENT SOLVENT EXTRACTION TABLE 14}

\begin{tabular}{|l|l|l|l|l|l|l|l|l|l|l|}
\hline $\begin{array}{l}\text { Plant } \\
\text { extraction }\end{array}$ & \multicolumn{1}{l}{$\begin{array}{l}\text { E.coli } \\
\boldsymbol{M}\end{array}$} & \multicolumn{1}{c}{$\boldsymbol{H}$ Klebsilla } \\
$\boldsymbol{M} \boldsymbol{H}$ & \multicolumn{2}{l}{$\begin{array}{l}\text { Salmonella } \\
\boldsymbol{M} \boldsymbol{H}\end{array}$} & \multicolumn{2}{l}{$\begin{array}{l}\text { Streptococcus } \\
\boldsymbol{M} \boldsymbol{H}\end{array}$} & \multicolumn{2}{l|}{$\begin{array}{l}\text { Staphylococcus } \\
\boldsymbol{M} \boldsymbol{H}\end{array}$} \\
\hline C.papaya & No & No & No & No & $15 \pm 1$ & 10 & $10 \pm 1$ & $5 \pm 2$ & No & No \\
\hline I.gooseberry & No & No & $3 \pm 1$ & No & No & No & No & No & No & No \\
\hline Menthaspicata & $10 \pm 2$ & $7 \pm 3$ & $4 \pm 1$ & $2 \pm 1$ & $20 \pm 1$ & $19 \pm 2$ & $6 \pm 1$ & $5 \pm 2$ & $5 \pm 1$ & No \\
\hline Pomengrate & $9 \pm 3$ & No & $13 \pm 2$ & $15 \pm 1$ & $15 \pm 1$ & 10 & $27 \pm 3$ & $21 \pm 1$ & $10 \pm 1$ & $5 \pm 1$ \\
\hline s.nigrum & No & No & No & No & No & No & $10 \pm 2$ & $9 \pm 3$ & No & No \\
\hline
\end{tabular}

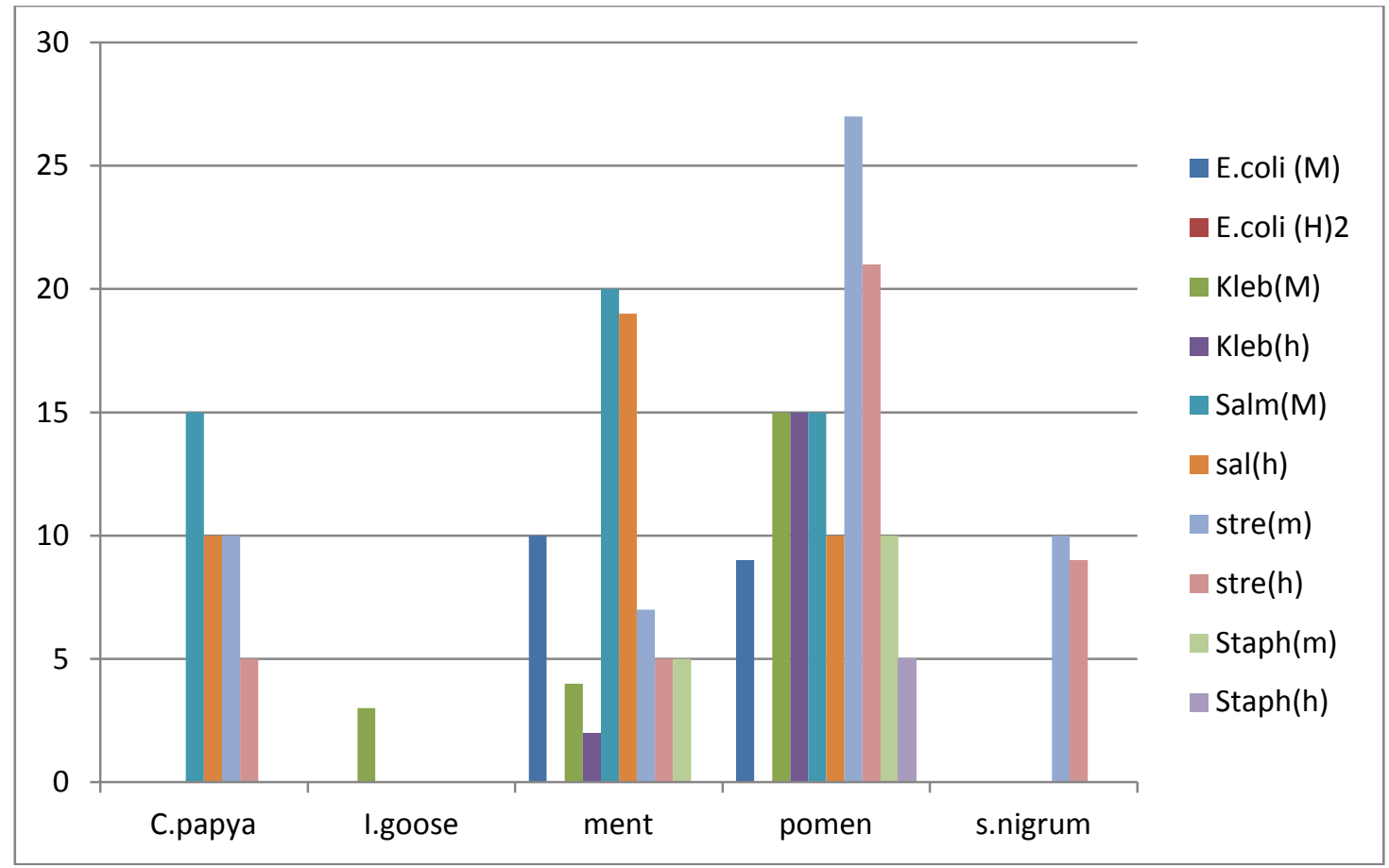

H-HEXANE M-METHANOL 


\section{SUMMARY AND CONCLUSION}

$\checkmark$. The plants are having lot of medicinal properties and we can use in normal life. It is extensively used in Ayurveda medicine and folk medicine .

$\checkmark$ We can use home plants such as pomengrate (Punica-granatum), Indian goose berry(alma) ,Solanum nigrum, Mentha spicata (Menthol), Carciya papaya(papaya) The present study to investigate and screening the phytochemical contents from the plant extracts .

$\checkmark$ All the five plants are had flavonoid, tannin phenols terphenols, carbohydrates, Phlobotanin, alkaloid. Andantioxidant, antimicrobial activity.Also quantitative Method to indicate presence of antioxidants and total content of flavonoid, ascorbic acid, tannin,total antioxidants are higher in Carciya papaya.Compare to Solanumnigrum,pomengrate, Indian goose berry,Mentha spicata had lower activity.

$\checkmark$ Antimicrobial activity was identified using different microorganisms'. The microorganisms such as Klebsilla, Salmonella, Staphylococcus aureus, Streptococcus, Escherichia coli. The antimicrobial activity is had higher activity from pomengrate and Carciyapapaya, compare to other plants extracts.

$\checkmark$ We can use plant disc and different solvent extracts are methanol and hexane to screen the microbial activity of plant extracts. It is higher from activity Mentha spicata and pomengrate compare to Carciyapapaya,Solanum nigrum, and Indian goose berry.

$\checkmark$ The minimal inhibitory concentration of plant extracts are higher activity from pomengrate. Thin layer chromatography are separate the plant extracts it can be produce the brown colour, black yellow conformation for flavonoid ,caumarrins, quinone. $\checkmark$ TLC slides are used to bio autography. Solanum nigrum pomengrate,Mentha spicata ,carciya papaya had inhibition activity produce red and violet colour we conclude carciya papaya, pomengrate ,Mentha spicata had lot of medicinal properties .Further we can say about the plants are used in normal in life only fruits but the leaves are had lot of medicinal properties. This are the plants leaves are used in thousands of years for medicinal uses only.

$\checkmark$ The plant leaves are taken in any type either tea or juice and food consumption. These plants are helps to cardiac disease, iron deficiency, inflammatory lung disease, and autoimmune arthritis, weight reduction, Diabetics.

\section{REFERENCES}

1. Acharya E, Pokhrel B. 2006, Ethnomedicinal plants used by Bantar of Bhaudaha, Nepal. Our Naturevol 4 ,pp96103.

2. Aiyeloja A. and Bello O.A. 2006, Ethnobotanical potentials of common herbs in Nigeria:A case study of Enugustate. Educational Research and Reviewvol 1 ,pp16-22.

3. Aliyu, A.B., Musa, A.M., Ibrahim, M.A., 1,Ibrahim, H. and Oyewale, A.0.2009 ,Preliminary phytochemical screening and antioxidant activity of leave extract of albiziachevalieri harms (Leguminoseaemimosoideae) BayeroJournal of Pure and Applied Sciences, vol 2 pp149 - 153

4. Arabshahi-Delouse ,Surooj,2009 Antioxident properties of various solvent extracts of mulberry leaves .Food chemis.vol102, pp1233-1240

5. Aravind, G., Bhowmik, D., Duraivel, S., \& Harish, G. 2013. Traditional and Medicinal Uses of Carica papaya.Journal of Medicinal Plants Studies, vol1, 7-15. 
6. Atta , 1999.carciyapappaya: Review of pharmacological and therapeutic properties , IJPSR ,vol3 ,pp 1240-1245

7. Ayoola GA, Sofidiya T, Odukoya O, Coker H.A.B ,2006, Phytochemical screening and free radical scavenging activity of some Nigerian medicinal plants. J. Pharm. Sci. \& Pharm. Practcal.Vol8 ,pp133-136.

8. BeheraSaiprasanna, Babu S Manohar, Ramani Y Roja, ChoudhuryPrasanta , PanigrahiRajeshree,2012,phytochemical investigation and study on antioxidant properties of ocimumcanumhydroalcoholic leaf extracts, Journal of Drug Delivery \&Therapeutics; vol 4, 122-128,

9. Bhattacharya A, Chatterjee A, Ghosal S, Bhattacharya SK.1999 ,Antioxidant activity of active tannoid principles of Emblicaofficinalis (amla). Indian $J$ ExpBiolvol 7, pp676-80.

10. Biswas K., Karan T.K., Bhattacharya S., Ghosh A.K., Haldar P.K., 2011, Evaluation of analgesic and antiinflammatory activities of Terminaliaarjuna leaf. Journal ofPhytology. Vol3: pp33-38.

11. Bruce, S. and Peter, C. A. 2008, Handbook of environmental physiology of fruit crops. 1st Ed. p.217.

12. Hedge Chaitra ,Maduri ,swaroop ,T.Nisshitha, Das arijith, 2012,Evalution of antimicrobial properties, phytochemical contents and antioxident capacities of leaf extracts of punicagranatum L. ISCA journal of biological sciences, vol 1 32-35-

13. Chan, L. W., Cheah, E. L. C., Saw, C. L. L., Weng, W., \&Heng, P. W. S. 2008, Antimicrobial and antioxidant activities of Cortex MagnoliaeOfficinalis and some other medicinal plants commonly used in South East Asia.Chinese medicine, vol 3, pp1123-1128

14. Chandra, S.; Mejia, E.G. 2004, Polyphenolic compounds, antioxidant capacity, and quinine reductase activity of an aqueous extract of Ardisiacompressain comparison to mate (Ilex paraguariensis) and green (Camellia sinensis) teas. J. Agric. Food Chemvol52,pp 3583-3589.

15. Chatterjee, A.S.C.P., 1994. The Treatise on Indian Medicinal Plants. Vol. III. Publication and Information Directorate. Council of Scientific and Industrial Research. New Delhi.

16. Chithra V, Leelamma. J2000 ,Ethnopharmacol; 71 pp 457-463.

17. Cooper MR, Johnson AW 1984. Poisonous Plants in Britain and other effects on Animals and Man. Ministry of Agriculture, Fisheries Food, vol 161pp 219-220.

18. DebjitBhowmik, Harish Gopinath1, B. Pragati Kumar1, S.Duraivel1, Aravind. G K. P. Sampath Kumar 2013, Journal of Pharmacognosy and Phytochemistry, Volume 5 pp128-135

19. Deepagarg,AdityaMuley, NishthaKhare, Thankamanimaran,2012 ,comparative analysis of phytochemical profile and antioxidant activity of some indian culinary herbs, Rjpbcs, vol 3, 845-851 .

20. Dubey NK, Kumar R and Tipathi P2004 ,Global promotion of herbal medicine: India's oppoliunity. Current Science, vol 86: pp37-41,

21. Dutra, R.C.; Leite, M.N.; Barbosa, N.R. 2011, Quantification of phenolic constituents and antioxidant effects of Solanum nigrum chloroform extract in animal models. J Med Food. Vol 14 pp 62-6.

22. F. O. Atanu1, U. G. Ebiloma1 and E. I. Ajayi2011 , A review of the pharmacological aspects of Solanum nigrum Linn. Biotechnology and Molecular Biology Review Vol. 6, pp. 001-007,

23. Felix AlexandreAntunesSoares and MargarethLindeAthayde2008, Antioxida nt Activity and Phytochemical Composition of the Leaves of 
Solanumguaraniticum ,Moleculesvol 17, 12560-12574.

24. Ganju L, Karan D, Chanda S, Srivastava KK, Sawhney RC, Selvamurthy W. 2003, Immunomodulatory effects of agents of plant origin. Biomed Pharmacothervol 7pp296-300.

25. Ghosal S, Tripathi VK, Chauhan S.1996, Active constituent of Emblicaofficinalis: part 1st the chemistry and antioxidant effects of two new hydrolysable tannins, emblicanin A and B. Indian J Chem.; vol 35pp 941-948.

26. Gow-chin Y, Pin-Der D. 1994 ,Scavenging Effect of methanolic Extracts of Peanut Hulls on Free-Radical and Active-oxygen Species. J. Agric Food Chem. Vol 42 pp629-632.

27. Gupta V., Sharma M.2011, Screening of three Indian medicinal plants extracts for antioxidant activity. International Journal of Institutional Pharmacy and Life Sciences, vol1pp 118-137.

28. J.Rameshwar Naidu1， R B Ismail1, Chen Yeng, Sasidharan .and Kumar,2012, Chemical composition and antioxidant activity of the crude methanolic extracts of Mentha spicata ,Journal of Phytology, vol 4pp 13-18.

29. Jain SK, akhurdiya DS. Anola,2000, Potential fruit for processing ,Delhi Garden Megavol 38 pp50-51.

30. Kulkarni AG, Suryakar AN, Sardeshmukh AS, Rathi DB.2007, Studies on Biochemical Changes with Special Reference to Oxidant and Antioxidants in Malaria Patients. Ind. J. Clin. Biochemvol 3 pp324-326

31. Kumaran, A., \& Joel Karunakaran, R. 2007, In vitro antioxidant activities of methanol extracts of five Phyllanthus species from India. LebensmittelWissenschaft und- Technologie,journal of science, vol 40, 344-352.

32. Mathur R, Sharma A, Dixit VP, Varma M.1996 ,Hypolipidaemic effect of fruit juice of Emblicaofficinalis in cholesterolfed rabbits. J Ethnopharmacol.; vol 2 pp61-68.

33. Madhuri.,Kaur M., Kaur G., Kaur H., 2013 ,Fever treatment with Carica papaya leaves extracts.. J Tropical Biomedicine vol2 pp 330-333.

34. Mohammad Ali Ebrahimzadeh, FereshtehPourmorad and Ahmad Reza Bekhradnia , 2008 , Iron chelating activity, phenol and flavonoid content of some medicinal plants from Iran , African Journal of Biotechnology Vol. 7 , pp. 3188-3192, ,

35. Nisar A., Hina F., Muhammad A., Bilal H. A., Ijaz M. and Lubna F. D. 2011, Fever treatment with Carica papaya leaves extracts. Asian Pacific .J Tropical Biomedicinevol12 pp330-333

36. Nisha P, Singhal RS, Pandit AB.2013, A study on degradation kinetics of ascorbic acid in amla (Phyllanthusemblica L.) during cooking. IntJ Food SciNutr. 5 pp:415-422.

37. Onions, Alan, 1994,Siddha Medicinal Herbs as Cosmetics Ingredients. SPC, vol 1 ,pp245-249

38. P.B. Ayoola\& A. Adeyeye ,2010,phytochemical and nutrient evaluation of carica papaya (pawpaw) leaves, ijrrasvol5 pp 325-328

39. Peschel,W.;Sanchez -Rabaneda ,F;Dn,W.Plehcer,A,;Gartizia,2011,An industrial approach in the natural antioxidents from vegetable and fruit wastes . Food chemist Vol,pp129-137

40. Pornpimon

Mayachiew,

SakamonDevahastin 2008, Antimicrobial and antioxidant activities of Indian gooseberry and galangal extracts, $L W T$ 41vol 2 pp1153-1159

41. Pourmorad F, Hossemimehr S, Shahabimajd N.2006, Antioxidant activity, phenol and flavonoid contents of some selected Iranian medicinal plant.Afr J of Biotechnolvol 5 pp1142-1145. 
42. Qnais E.Y. A.S., Abughalyan Y.Y. and abdulla F.A 2007, Anti diarreal activity of the aqueous extract of punicagranatum ( pomengrate) .pharma . biol., vol 5 pp 715720-

43. RashaSaad, Tan Pohyeen, JiyauddinKhan, Li Wenji, SadiaSultan, JunainahAbdulHameed, Eddy1993, phytochemical screening and antioxidant activity of different parts frompunicagranatum ,journal of science, ,vol 2 pp 876880

44. Rastogi RP, Mehrotra BN. 1993,Compendium of Indian Plants. CDRI, Lucknow and Publications \& Information Directorate, New Delhi,

45. Robson Borba de Freitas, Michel Mansur Machado, Sílvio Terra Stefanello 2009, plant Extracts Molecules, vol,14,pp2167-2180;

46. SadikaAkhter, Md. Ismail Hossain , Md. AminulHaque2012, Phytochemical Screening, Antibacterial, Antioxidant and Cytotoxic Activity of the Bark Extract of TerminaliaArjunaEuropean Journal of Scientific ResearchISSN 1450-216X Vol. 86 , pp.543-552.

47. Samy R.P. pushparaj and gopalakrishnan P.A., 2008,compilation of bioactive compounds from ayurveda, Bioinformationvol 3 pp100-110

48. .Sineen, H.; Devi, K.S.2003Antioxidant activities of the chloroform extract of Solanumtrilobatum.Pharm. Biol., vol42, 462-466.

49. Senthilnathpushparaj and gopala krishnan 2013, Antinociceptive, antiinflammatory and antipyretic Emblicaofficinalis - diabetic cataract in rats. Mol Vol.;1pp 129-13

50. Stuart GA. 2014 Chinese MateriaMedica Vegetable Kingdom. American Presbyterian Mission Press, Shanghai, (1911) 558.
51. Tiwari P., Kumar B., Kaur M., Kaur G., Kaur H., 2011. Phytochemical screening and Extraction: A Review. International PharmaceuticaSciencia. Vol 1pp 103-104

52. Valko ,Vasu K, Goud JV, Suryam A, Singara Chary MA 200,. Biomolecular and phytochemical analyses of three aquatic angiosperms. Afr J Microbiol Res; vol 3 pp418-421

53. Zakaria ZA, Gopalan HK, Zainal H, et al.,2006, Antinociceptive, anti-inflammatory and antipyretic Emblicaofficinalis and its enriched tannoids delay streptozotocin-induced diabetic cataract in rats. Mol Vol.;13pp 1291-1297

54. Zhu, N., Wang, M., Wei, G.J., Lin, J.K., Yang, C.S.Ho, C.T. 2001, Identification of reaction products of epigallocatechin, (-) epigallocatechingallate and pyrogallol with 1, 1-diphenyl-2picrylhydrazyl radical. Food Chem.,vol 73pp 345-349 